\title{
Calcium Oscillations
}

\author{
Geneviève Dupont ${ }^{1}$, Laurent Combettes ${ }^{2}$, Gary S. Bird ${ }^{3}$, and James W. Putney ${ }^{3}$ \\ ${ }^{1}$ Unité de Chronobiologie Théorique, Université Libre de Bruxelles, Faculté des Sciences CP231, \\ Boulevard du Triomphe, B-1050 Brussels, Belgium \\ ${ }^{2}$ Institut National de la Santé et de la Recherche Médicale Unité U442, Université de Paris-Sud, Bât 443, \\ 91405 Orsay, France \\ ${ }^{3}$ National Institute of Environmental Health Sciences-NIH, Department of Health and Human Services, \\ PO Box 12233, Research Triangle Park, North Carolina 27709 \\ Correspondence: susanh@bcm.edu
}

Calcium signaling results from a complex interplay between activation and inactivation of intracellular and extracellular calcium permeable channels. This complexity is obvious from the pattern of calcium signals observed with modest, physiological concentrations of calcium-mobilizing agonists, which typically present as sequential regenerative discharges of stored calcium, a process referred to as calcium oscillations. In this review, we discuss recent advances in understanding the underlying mechanism of calcium oscillations through the power of mathematical modeling. We also summarize recent findings on the role of calcium entry through store-operated channels in sustaining calcium oscillations and in the mechanism by which calcium oscillations couple to downstream effectors.

C alcium ions participate in a multiplicity of physiological and pathological functions. Among the most intensely studied, and the major focus of this article, is the role of $\mathrm{Ca}^{2+}$ as a cellular signal. Elevations in cytoplasmic $\mathrm{Ca}^{2+}$ mediate a plethora of cellular responses, ranging from extremely rapid events (muscle contraction, neurosecretion), to slower more subtle responses (cell division, differentiation, apoptosis). In contrast to most cellular signals, it is a relatively simple matter to observe changes in cytoplasmic $\mathrm{Ca}^{2+}$ in real time in living cells. As a result, the truly complex nature of $\mathrm{Ca}^{2+}$ signaling pathways has been revealed. The challenge is to understand what regulates these signals and what the biological significance of their complexity is.

In the majority of laboratory experiments examining effects of various stimulants on $\mathrm{Ca}^{2+}$ signaling, supramaximal concentrations of activating agonists are employed resulting in rapid, robust, and often sustained increases in cytoplasmic $\mathrm{Ca}^{2+}$. It has long been appreciated that these signals result from a coordinated release of intracellular stores and increased $\mathrm{Ca}^{2+}$ influx across the plasma membrane (Bohr, 1973; Putney et al. 1981). The intracellular release of $\mathrm{Ca}^{2+}$ most commonly results from the $\mathrm{Ca}^{2+}$ releasing action of the phospholipase $\mathrm{C}$-derived second messenger, inositol 1,4,5-trisphosphate

Editors: Martin D. Bootman, Michael J. Berridge, James W. Putney, and H. Llewelyn Roderick

Additional Perspectives on Calcium Signaling available at www.cshperspectives.org

Copyright (C) 2011 Cold Spring Harbor Laboratory Press; all rights reserved; doi: 10.1101/cshperspect.a004226

Cite this article as Cold Spring Harb Perspect Biol 2011;3:a004226 
G. Dupont et al.

$\left(\mathrm{InsP}_{3}\right)$ (Streb et al. 1983), whereas the entry of $\mathrm{Ca}^{2+}$ is because of the activation of store-operated channels in the plasma membrane (Putney 1986). However, it is becoming increasingly clear that these large sustained elevations seldom occur with physiological levels of stimulants. Rather the more common pattern of $\mathrm{Ca}^{2+}$ signaling, in both excitable and nonexcitable cells is a pattern of periodic discharges and/or entry of $\mathrm{Ca}^{2+}$. In excitable cells, such as the heart for example, these may be comprised of, or initiated by regenerative all-or-none plasma membrane channel activation, the $\mathrm{Ca}^{2+}$ action potential (Tsien et al. 1986) with amplification by intracellular $\mathrm{Ca}^{2+}$ release (Fabiato 1983). In nonexcitable cells, these spikes of cytoplasmic $\mathrm{Ca}^{2+}$ arise from regenerative discharge of stored $\mathrm{Ca}^{2+}$, a process generally termed $\mathrm{Ca}^{2+}$ oscillations (Prince and Berridge 1973; Woods et al. 1986). Like $\mathrm{Ca}^{2+}$ action potentials, these all-ornone discharges of $\mathrm{Ca}^{2+}$ represent a form of excitable behavior of the intracellular $\mathrm{Ca}^{2+}$ release signaling mechanism. However, because it is not possible to easily monitor and control the transmembrane chemical and biophysical parameters, as is the case for excitable plasma membrane behavior, it has been more difficult to fully understand the basic mechanisms by which these $\mathrm{Ca}^{2+}$ oscillations arise. Thus, although the question has been exhaustively studied for well over twenty years, there is still uncertainty and controversy over the underlying processes that give rise to $\mathrm{Ca}^{2+}$ oscillations. A number of reviews have discussed these issues at some length (Berridge and Galione 1988; Rink and Jacob 1989; Berridge 1990; Petersen and Wakui 1990; Berridge 1991; Cuthbertson and Cobbold 1991; Meyer and Stryer 1991; Hellman et al. 1992; Tepikin and Petersen 1992; Thomas et al. 1992; Dupont and Goldbeter 1993; Keizer 1993; Sneyd et al. 1994; Li et al. 1995; Thomas et al. 1996; Shuttleworth 1999; Lewis 2003; Dupont et al. 2007). In the current treatment, we have chosen to focus on two important aspects of $\mathrm{Ca}^{2+}$ oscillations. First, we review the available evidence for various computational models of $\mathrm{Ca}^{2+}$ oscillations that employ a quantitative approach to validate or repudiate specific mechanisms. Second, we consider the interrelationship between $\mathrm{Ca}^{2+}$ oscillations and plasma membrane $\mathrm{Ca}^{2+}$ influx mechanisms, with the view that we may learn more of the physiological function that these intracellular discharges of $\mathrm{Ca}^{2+}$ provide.

\section{COMPUTATIONAL MODELS FOR $\mathrm{Ca}^{2+}$ OSCILLATIONS}

Since the first observations of $\mathrm{Ca}^{2+}$ oscillations, the experimental investigation of their molecular mechanism has been accompanied by numerous modeling approaches. One of the reasons for this is that rhythmic phenomena are known to rely on specific, nonlinear feedback processes that cannot readily be fully approached by intuitive and qualitative reasoning. Likewise, cAMP oscillations, circadian rhythms, cell cycle-related variations of the activity of cyclin associated kinases or the tumor-associated $\mathrm{p} 53 / \mathrm{mdm} 2$ loop are other oscillatory phenomena in biology whose investigation largely benefits from a modeling approach (Goldbeter 2008). In the field of $\mathrm{Ca}^{2+}$ dynamics, modeling was also promoted by the fact that cytosolic $\mathrm{Ca}^{2+}$ was initially the only measurable variable of the system. This also prompted investigators to use modeling to identify the main messenger responsible for intra- or intercellular wave propagation when those spatially organized phenomena were reported in a variety of cell types (Thomas et al. 1996; Dupont et al. 2007). More recently, sub-cellular $\mathrm{Ca}^{2+}$ increases because of the opening of a small number of $\mathrm{Ca}^{2+}$ channels have also been simulated computationally. In this case, models offer the possibility to make the link between properties of the channels measured with electrophysiology and their behavior in the cytoplasm. In addition, simulations are required to understand how the regularity that is observed at the whole cell level (oscillations and waves) can emerge from the random behavior inherent to any ion channel.

One of the most attractive features about models is their ability to make experimentally testable predictions. That $\mathrm{Ca}^{2+}$ oscillations can occur in the presence of a constant level of $\mathrm{InsP}_{3}$ and that the self-amplification of $\mathrm{Ca}^{2+}$ release from the ER into the cytoplasm lies at 
the basis of $\mathrm{Ca}^{2+}$ oscillations was for example first predicted theoretically (Goldbeter et al. 1990). This regulation is known as $\mathrm{Ca}^{2+}$. induced $\mathrm{Ca}^{2+}$ release (CICR). However, this early model assumed that $\mathrm{Ca}^{2+}$ oscillations require the existence of 2 types of pools, some sensitive to $\mathrm{InsP}_{3}$ and others possessing $\mathrm{RyR}$ and thereby sensitive to $\mathrm{Ca}^{2+}$. This turned out not to be necessary as the $\mathrm{InsP}_{3} \mathrm{R}$ is itself sensitive to both $\mathrm{Ca}^{2+}$ and $\mathrm{InsP}_{3}$.

In the past 20 years, many computational models have been developed. They differ by the precise oscillations that they aim to describe, as determined both by the cell type and by the agonist. Models also vary according to the level of description, from microscopic (in which case stochastic modeling must be used) to macroscopic (corresponding to a deterministic description). Another, somewhat intermediate level of description allowing one to take easily spatial and stochastic aspects into account is known as "threshold models" (see below). In each case, several models differing by the specific underlying assumptions have been proposed. Such a classification is presented in Table 1, together with some typical models in each category. Although in this review we focus on $\mathrm{InsP}_{3}$ - regulated $\mathrm{Ca}^{2+}$ oscillations, we have also indicated in Table 1 models for $\mathrm{Ca}^{2+}$ oscillations because of plasma-membrane voltagegated $\mathrm{Ca}^{2+}$ channels or ryanodine receptors. Such models should be kept in mind when investigating $\mathrm{InsP}_{3}$-induced $\mathrm{Ca}^{2+}$ increases, especially in view of the fact that they could provide a secondary oscillatory mechanism in some cell types. For example, in pancreatic acinar cells (Ventura and Sneyd 2006) or airway smooth muscle cells (Wang et al. 2008); the interplay between $\mathrm{Ins}_{3} \mathrm{R}$ and RyR plays a major physiological role.

\section{Models for $\mathrm{Ca}^{2+}$ Oscillations With or Without Ins $\mathrm{P}_{3}$ Oscillations}

As the $\operatorname{Ins}_{3} \mathrm{R}$ is biphasically regulated by $\mathrm{Ca}^{2+}$ (Bezprozvanny et al. 1991; Finch et al. 1991), models that describe the changes of states of this receptor can on their own account for $\mathrm{Ca}^{2+}$ oscillations. Such $\mathrm{InsP}_{3} \mathrm{R}$-based models are numerous and mainly differ by their level of details, the most detailed being useful to dissect the quantitative effect of possible changes in kinetic constants and affinities. The simplest ones allow for a better understanding of the essence of the observed phenomena, as exemplified by the early CICR model mentioned above (Goldbeter et al. 1990). As another example, simplified models point to the fact that for oscillations to occur, activation by $\mathrm{Ca}^{2+}$ has to be much faster than inhibition. Some of these Ins $\mathrm{P}_{3} \mathrm{R}$-based models are indicated in Table 1 (class: Ins $\mathrm{P}_{3} \mathrm{R}$, constant $\mathrm{InsP}_{3}$ ) and readers should turn to (Sneyd and Falcke 2005) for a more comprehensive review of this type of model. All of these models face a common problem: the period of $\mathrm{Ca}^{2+}$ oscillations is imposed by the time taken by the receptor to recover from $\mathrm{Ca}^{2+}$-induced inhibition. However, this rate constant has been estimated experimentally to be of the order of approximately 10 seconds in vitro (Finch et al. 1991; Combettes et al. 1994) and of a few seconds in vivo (Fraiman et al. 2006). These time delays are significantly shorter than the observed periods of $\mathrm{Ca}^{2+}$ oscillations that frequently exceed 1 minute. Thus, modeling here brings to light a clearly important limitation in our understanding of the mechanism of $\mathrm{Ca}^{2+}$ oscillations.

Such a discrepancy could either be explained by the existence of an additional control of the $\mathrm{InsP}_{3} \mathrm{R}$ activity, such as agonist-induced PKA-dependent phosphorylation (LeBeau et al. 1999) or $\mathrm{InsP}_{3}$ - induced inactivation (Hajnóczky and Thomas 1994), or suggest that although CICR at the level of the $\operatorname{Ins}_{3} \mathrm{R}$ has the potential to generate oscillations, it is not the main oscillatory mechanism in vivo. Periodic variations in the concentration of $\mathrm{InsP}_{3}$ could indeed also drive $\mathrm{Ca}^{2+}$ oscillations, in which case the period would be imposed by the rates of $\mathrm{Ins}_{3}$ metabolism (right column in Table 1). This assumption was in fact at the basis of some early models for agonist-induced $\mathrm{Ca}^{2+}$ oscillations (Meyer and Stryer 1988; Cuthbertson and Chay 1991). In both models, cytosolic $\mathrm{Ca}^{2+}$ and $\mathrm{InsP}_{3}$ act as cross-catalytic messengers because $\mathrm{Ins}_{3}$ triggers $\mathrm{Ca}^{2+}$ release from the ER, which in turn activates $\mathrm{InsP}_{3}$ synthesis because 


\section{G. Dupont et al.}

Table 1. Schematic classification of the main types of computational models for intracellular $\mathrm{Ca}^{2+}$ oscillations.

\begin{tabular}{|c|c|c|c|c|c|}
\hline & \multicolumn{4}{|c|}{ Channels-based models } & \multirow{3}{*}{$\begin{array}{c}\mathrm{InsP}_{3} \\
\text { metabolism- } \\
\text { based models } \\
\\
\text { Active InsP } \\
\text { Oscillations }\end{array}$} \\
\hline & \multirow[b]{2}{*}{ Voltage-gated } & \multirow[b]{2}{*}{ RyR } & \multicolumn{2}{|c|}{$\operatorname{lns}_{3} \mathrm{R}$} & \\
\hline & & & Constant InsP 3 & $\begin{array}{c}\text { Passive InsP } \\
\text { oscillations }\end{array}$ & \\
\hline \multirow[t]{2}{*}{ Deterministic } & $\begin{array}{l}\text { Fioretti et al. } \\
\text { 2005; Zeng } \\
\text { et al. } 2009\end{array}$ & $\begin{array}{c}\text { Keizer and Levine } \\
\text { 1996; Tang and } \\
\text { Othmer } 1994\end{array}$ & $\begin{array}{l}\text { De Young and } \\
\text { Keizer 1992; Li } \\
\text { and Rinzel 1994; } \\
\text { Atri et al. 1993; } \\
\text { Dupont and } \\
\text { Swillens 1996; } \\
\text { Tang et al. 1996; } \\
\text { Bezprozvanny } \\
\text { 1994 }\end{array}$ & $\begin{array}{l}\text { Dupont and } \\
\text { Erneux } 1997\end{array}$ & $\begin{array}{l}\text { Meyer and } \\
\text { Stryer 1988; } \\
\text { Cuthbertson } \\
\text { and Chay 1991 }\end{array}$ \\
\hline & & & & \multicolumn{2}{|c|}{$\begin{array}{l}\text { De Pitta et al. 2009; Kummer et al. } \\
\text { 2000; Höfer et al. } 2002\end{array}$} \\
\hline Threshold & & & $\begin{array}{l}\text { Dawson et al. 1999; } \\
\text { Coombes et al. } \\
\text { 2004; Thul et al. } \\
2008\end{array}$ & & \\
\hline Stochastic & & $\begin{array}{r}\text { Zahradnikova and } \\
\text { Zahradnik } 1996\end{array}$ & $\begin{array}{l}\text { Falcke 2004; Shuai } \\
\text { et al. 2009; } \\
\text { Williams et al. } \\
2008\end{array}$ & & $\begin{array}{l}\text { Kummer et al. } \\
2005\end{array}$ \\
\hline
\end{tabular}

In each category, only representative examples are indicated. Models indicated in the frame overlapping two columns are based on two distinct oscillatory mechanisms, one based on the $\operatorname{InsP}_{3} \mathrm{R}$ and one based on InsP $\mathrm{P}_{3}$ metabolism.

PLC is assumed to be stimulated by physiological levels of $\mathrm{Ca}^{2+}$. This regulation of PLC activity by $\mathrm{Ca}^{2+}$ in the $0.1-1 \mu \mathrm{M}$ range has been observed for the $\delta$ (Allen et al. 1997) and $\zeta$ isoforms (Kouchi et al. 2004) but not for the $\beta$ (Renard et al. 1987), which is the isoform coupled to the G-protein pathway that is most frequently associated with hormone stimulation. However, these models differ in their assumptions about the nature of the negative feedback process required to switch off the $\mathrm{Ca}^{2+}$ rise. Meyer and Stryer (Meyer and Stryer 1988) assumed that $\mathrm{Ca}^{2+}$ started to decrease in the cytoplasm because of rapid pumping into the mitochondria, whereas Cuthbertson and Chay (Cuthbertson and Chay 1991) presumed that $\mathrm{Ca}^{2+}$-activated PKC would down-regulate the G-proteins transducing receptor stimulation to PLC activation. Models for $\mathrm{Ca}^{2+}$ oscillations induced by $\mathrm{InsP}_{3}$ oscillations fell somewhat into disfavor when the biphasic $\mathrm{Ca}^{2+}$ sensitivity of the Ins $\mathrm{P}_{3} \mathrm{R}$ was discovered. Still, some models drew attention to the fact that oscillations in $\mathrm{InsP}_{3}$ could occur because of the activation of $\mathrm{InsP}_{3}$ catabolism by $\mathrm{Ca}^{2+}$. As one of the Ins $\mathrm{P}_{3}$ - metabolizing enzymes, the inositol 1,4,5-trisphosphate 3-kinase, is stimulated by the $\mathrm{Ca}^{2+} /$ calmodulin complex, each peak in $\mathrm{Ca}^{2+}$ induces a decrease in $\mathrm{InsP}_{3}$ (Dupont and Erneux 1997). Models taking this regulation into account predict the concomitant occurrence of InsP $\mathrm{P}_{3}$ and $\mathrm{Ca}^{2+}$ oscillations. Interestingly, they also predict that these passive $\mathrm{InsP}_{3}$ oscillations do not significantly affect the timing of the $\mathrm{Ca}^{2+}$ spikes (Dupont and Erneux 1997; Dupont et al. 2003; Tanimura et al. 2009).

$\mathrm{InsP}_{3}$ oscillations were reported in some cell types by monitoring the translocation of green 
fluorescent protein (GFP) tagged to the pleckstrin homology $(\mathrm{PH})$ domain of PLC, thus reawakening interest for models based on oscillatory production of $\mathrm{Ins}_{3}$ (Taylor and Thorn 2001). Interestingly, concomitant oscillations of both InsP $\mathrm{P}_{3}$ and $\mathrm{Ca}^{2+}$ have been mostly observed in cell lines expressing the mGluR5 receptor. These glutamate-induced $\mathrm{Ca}^{2+}$ oscillations have unusual characteristics: most importantly, oscillations occur over a wide range of agonist concentration, their frequency is practically insensitive to the level of stimulation, and they are inhibited by PKC inhibitors. It is thus plausible that depending on the receptor type, different oscillatory mechanisms would prevail. In recent models for such types of oscillations, both oscillatory mechanisms (i.e., InsP $\mathrm{P}_{3} \mathrm{R}$-based and $\mathrm{InsP}_{3}$ metabolism-based) are considered at the same time (Kummer et al. 2000; Hofer et al. 2002; De Pitta M. et al. 2009). This allows the period of Ins $P_{3} R$-based $\mathrm{Ca}^{2+}$ oscillations to be controlled by the rate of $\mathrm{InsP}_{3}$ synthesis, through the regulation of either PLC or PKC by $\mathrm{Ca}^{2+}$.

Modeling has also been used to define experimental tests that could discriminate between an Ins $\mathrm{P}_{3} \mathrm{R}$-based and an Ins $\mathrm{P}_{3}$ metabolism-based

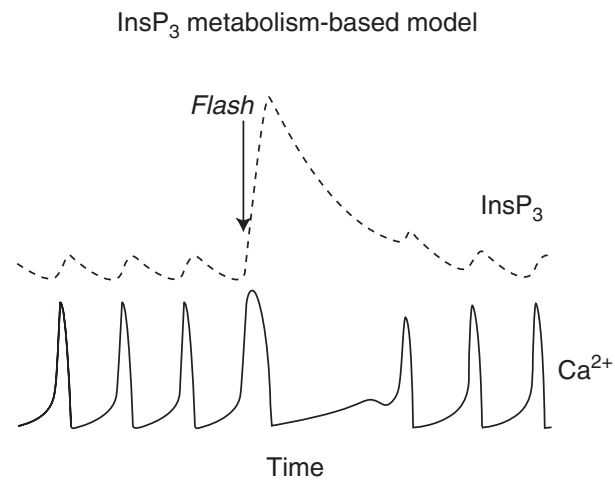

mechanism. Sneyd et al. (2006) proposed to perturb agonist-induced $\mathrm{Ca}^{2+}$ oscillations by the direct, artificial release of $\mathrm{Ins}_{3}$ in the cytoplasm (flash photolysis of caged $\mathrm{Ins}_{3}$ ). As shown in Figure 1, the pattern of the $\mathrm{Ca}^{2+}$ rise after such a spike very much depends on the underlying oscillatory mechanism. In a model where $\mathrm{InsP}_{3}$ metabolism is at the basis of $\mathrm{Ca}^{2+}$ oscillations, this sudden increase in $\mathrm{Ins}_{3}$ will provoke a delay in the occurrence of the next $\mathrm{Ca}^{2+}$ spike, which corresponds to the time required for the level of $\mathrm{InsP}_{3}$ to go back to its normal range of concentrations during oscillatory cycles. Once this is done, the situation is similar to the prepulse one and no change in frequency is observed as clearly shown in the left panel of Figure 1 . The situation is drastically different for $\mathrm{Ca}^{2+}$ oscillations occurring with a constant level of $\mathrm{InsP}_{3}$ because of the sequential activation and inhibition of the $\mathrm{InsP}_{3} \mathrm{R}$. In the framework of such a mechanism, the frequency of $\mathrm{Ca}^{2+}$ oscillations directly depends on the (constant) level of Ins $\mathrm{P}_{3}$. Thus, a sudden increase in Ins $\mathrm{P}_{3}$ during agonist-induced $\mathrm{Ca}^{2+}$ oscillations provokes a transient rise in frequency (Fig. 1, right panel). The interspike interval then progressively decreases to the period of the unperturbed

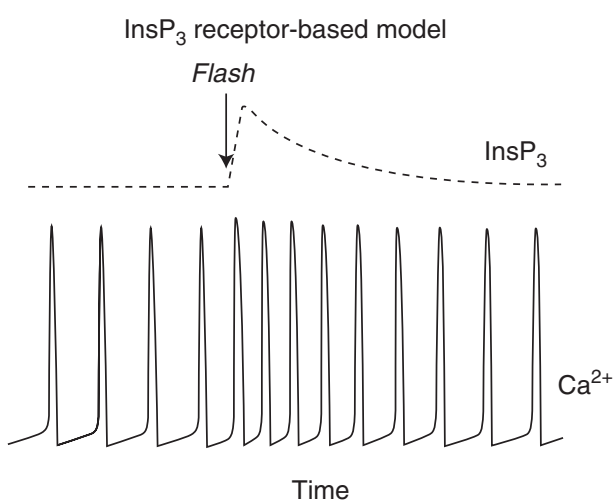

Figure 1. Schematic representation of the protocol proposed by Sneyd et al. (2006) to discriminate between an Ins $\mathrm{P}_{3} \mathrm{R}$-based or an Ins $\mathrm{P}_{3}$ metabolism-based mechanism for $\mathrm{Ca}^{2+}$ oscillations. If phospholipase C (PLC) activity is stimulated by $\mathrm{Ca}^{2+}$ (left panel), oscillations in InsP $\mathrm{P}_{3}$ must accompany $\mathrm{Ca}^{2+}$ oscillations. If some $\mathrm{InsP}_{3}$ is exogenously added during $\mathrm{Ca}^{2+}$ oscillations, it will delay the next $\mathrm{Ca}^{2+}$ spikes, without significant change in the frequency of $\mathrm{Ca}^{2+}$ oscillations. In contrast (right panel), if $\mathrm{Ca}^{2+}$ oscillations rely on successive cycles of activation/inhibition of the $\mathrm{InsP}_{3}$ receptor $\left(\mathrm{InsP}_{3} \mathrm{R}\right), \mathrm{Ca}^{2+}$ oscillations can occur with a constant level of InsP $\mathrm{P}_{3}$. In this case, the addition of $\mathrm{InsP}_{3}$ during oscillations will provoke a transient rise in the frequency of $\mathrm{Ca}^{2+}$ oscillations, with a progressive return to the original frequency. See text and Sneyd et al. (2006) for details. 
G. Dupont et al.

system. The number of spikes necessary to the resettlement of the prepulse periodicity increases with the amount of $\mathrm{InsP}_{3}$ released into the cell (Sneyd et al. [2006]; see also Chatton et al. [1998]).

To test this hypothesis, InsP $\mathrm{P}_{3}$ was released by flash photolysis in methacholine-stimulated pancreatic acinar cells and in carbachol-stimulated smooth muscle cells. In pancreatic acinar cells, liberation of $\mathrm{InsP}_{3}$ during agonist-induced $\mathrm{Ca}^{2+}$ oscillations provoked a delay similar to the one shown in the left panel of Figure 1, suggesting that PLC activation by $\mathrm{Ca}^{2+}$ plays a predominant role in the oscillatory mechanism in this cell type. In contrast, the release of $\mathrm{InsP}_{3}$ during methacholine-induced $\mathrm{Ca}^{2+}$ oscillations in airway smooth muscle cells provokes a transient acceleration of $\mathrm{Ca}^{2+}$ oscillations, as that seen in the right panel of Figure 1. It is thus concluded that in this cell type, $\mathrm{Ca}^{2+}$ oscillations rely on the $\mathrm{InsP}_{3} \mathrm{R}$ dynamics. More recently, Swann and Yu (Swann and Yu 2008) have applied the same testing protocol to fertilization-induced $\mathrm{Ca}^{2+}$ oscillations in mouse eggs. As in panel $\mathrm{A}$ of Figure 1, the InsP $\mathrm{P}_{3}$ pulse induced an immediate $\mathrm{Ca}^{2+}$ spike followed by a delay longer than the period of oscillations before the next one. The return to the prepulse periodicity was straightforward. This is compatible with a mechanism whereby $\mathrm{InsP}_{3}$ metabolism drives $\mathrm{Ca}^{2+}$ oscillation, in agreement with the fact that PLC $\zeta$, the PLC isoform triggering $\mathrm{Ca}^{2+}$ oscillations in mammalian eggs, is activated by physiological $\mathrm{Ca}^{2+}$ levels (Saunders et al. 2002; Dupont and Dumollard 2004).

A second indirect method to assess the involvement of Ins $\mathrm{P}_{3}$ dynamics in the core oscillatory mechanism has been tested in $\mathrm{CHO}$ cells (Politi et al. 2006). This method is based on the slowing down of $\mathrm{InsP}_{3}$ dynamics with an $\mathrm{InsP}_{3^{-}}$- binding protein that acts as an "InsP $\mathrm{P}_{3}$ buffer." As buffers change the kinetics but not the steady states, this compound would only affect $\mathrm{Ca}^{2+}$ oscillations relying on $\mathrm{InsP}_{3}$ metabolism (as InsP ${ }_{3} \mathrm{R}$-based oscillations occur with a constant level of $\mathrm{InsP}_{3}$ ). Moreover, the slowingdown of InsP $\mathrm{P}_{3}$ variations is assumed to affect intracellular dynamics only if $\mathrm{InsP}_{3}$ oscillations rely on activation of $\operatorname{InsP}_{3}$ synthesis by $\mathrm{Ca}^{2+}$
(PLC) and not stimulation of $\operatorname{InsP}_{3}$ catabolism by $\mathrm{Ca}^{2+}$ (3-kinase). This protocol was applied in ATP-stimulated $\mathrm{CHO}$ cells transfected with an $\mathrm{InsP}_{3}$ - binding protein. These cells showed a dose-dependent quenching of $\mathrm{Ca}^{2+}$ oscillations, suggesting a PLC-based oscillatory mechanism in this cell type.

\section{Models for $\mathrm{Ca}^{2+}$ Oscillations Taking Stochastic Aspects Into Account}

All of the models discussed in the previous section are deterministic. This means that the effects of fluctuations (because of internal noise and microscopic inhomogeneities) are neglected. This is the common approach in modeling biochemical and chemical systems when the numbers of molecules involved in the process under interest are sufficiently large. In this case, stochastic fluctuations do not affect the average behavior of the ensemble, mainly because they statistically cancel each other out. For example, in electrophysiology, it is well known that the behavior of a few channels is random, but that the dynamics of neurons are very well described by deterministic equations of the Hodgkin-Huxley type.

An impressive number of studies have been devoted to the imaging of the $\mathrm{Ca}^{2+}$ releasing activity of a small number of $\mathrm{InsP}_{3}$ receptors in vivo. These can occur either spontaneously or at submaximal $\mathrm{InsP}_{3}$ concentrations. As expected, these events appear to be inherently stochastic. Their amplitude and the interval among them vary significantly under the same conditions, allowing only for a statistical description. The smallest observed events, called blips, involve a rise in cytosolic $\mathrm{Ca}^{2+}$ of about $40 \mathrm{nM}$ and last in average $70 \mathrm{~ms}$. These blips are believed to correspond to successive openings of a single $\mathrm{Ins}_{3}$ receptor in the cytoplasm. This is possible because of the poor diffusing properties of $\mathrm{Ca}^{2+}$ in the cytoplasm allowing for rapid rebinding of $\mathrm{Ca}^{2+}$ on the channel activating sites, as indicated by quantitative models (Swillens et al. 1998). Alternatively, openings of one Ins $\mathrm{P}_{3} \mathrm{R}$ may trigger other Ins $\mathrm{P}_{3} \mathrm{Rs}$ within a cluster to generate slightly larger $\mathrm{Ca}^{2+}$ increases known as $\mathrm{Ca}^{2+}$ puffs. The rise in $\mathrm{Ca}^{2+}$ is then 
about $200 \mathrm{nM}$ and lasts approximately $300 \mathrm{~ms}$. Blips and puffs have been extensively studied in HeLa cells (Thomas et al. 2000; Bootman et al. 2002) and Xenopus oocytes (Marchant et al. 1999; Smith and Parker 2009). These elementary events have been modeled using a stochastic description of the dynamics of the $\mathrm{InsP}_{3} \mathrm{R}$ (Swillens et al. 1999; Williams et al. 2008; Smith et al. 2009). These have for example allowed prediction of the approximate number of Ins $\mathrm{P}_{3} \mathrm{Rs}$ present in a cluster site (Swillens et al. 1999). As we will see below, this notion of clustering of $\mathrm{Ins}_{3}$ receptors, necessary to explain the existence of puffs, has important implications in our understanding of global $\mathrm{Ca}^{2+}$ signals at the cell level.

In experiments, a rise in the level of InsP $\mathrm{P}_{3}$ transforms stochastic, elementary $\mathrm{Ca}^{2+}$ increases into regular, periodic $\mathrm{Ca}^{2+}$ increases propagating as waves in the cytoplasm. This transition would correspond to the fact that the rise in $\mathrm{InsP}_{3}$ leads to an increase in the number of channels participating in the $\mathrm{Ca}^{2+} \mathrm{dy}$ namics. Thus, the effect of fluctuations would become rather small, allowing the transition into a deterministic regime (i.e., a regime in which the behavior of the system can be predicted, as opposed to random processes). To test this hypothesis, we have performed a statistical analysis of the regularity of $\mathrm{Ca}^{2+}$ oscillations in noradrenaline-stimulated hepatocytes and found that the coefficient of variation of the period lies between $10 \%$ and $15 \%$. Stochastic simulations taking into account realistic numbers of InsP $\mathrm{P}_{3} \mathrm{Rs}$ (about 6000 in a typical hepatocyte) accounted for such variability, if the receptors are assumed to be grouped in clusters of a few tens of channels (Dupont et al. 2008; Dupont and Combettes 2009). This supports the idea that repetitive $\mathrm{Ca}^{2+}$ spiking can be described as a deterministic oscillator. However, as the number of clusters is rather low, this oscillator is perturbed by noise leading to the $10-15 \%$ variation in the period. In agreement with this view, this coefficient of variation decreases with increasing levels of $\mathrm{InsP}_{3}$, as the number of active channels increases. That this is the case both in the model and in hepatocytes is shown in Figure 2.
It has also been proposed that even at the cellular level, $\mathrm{Ca}^{2+}$ dynamics are intrinsically stochastic. The reason for that would lie in the spatial arrangement of the $\mathrm{InsP}_{3} \mathrm{Rs}$ in clusters spaced from each other by a few microns. As $\mathrm{Ca}^{2+}$ is a poorly diffusible messenger in the cytoplasm, the $\mathrm{Ca}^{2+}$ rise occurring at one puff site would be unable to activate release from adjacent sites. This absence of communication would prevent global signaling. Thus, $\mathrm{Ca}^{2+}$ waves could be initiated only if, by chance, a sufficient number of clusters of Ins $\mathrm{P}_{3} \mathrm{Rs}$ become active at the same time. This process, called nucleation, would lead to a $\mathrm{Ca}^{2+}$ increase that is large enough to activate all the $\mathrm{InsP}_{3}$ - bound Ins ${ }_{3} \mathrm{Rs}$ and generate a $\mathrm{Ca}^{2+}$ spike. In this type of modeling, the variation of the period is of the order of the period itself (Falcke 2004; Skupin et al. 2008). Interestingly, in this framework, spike initiation that corresponds to the time required for the concomitant opening of a few adjacent cluster sites can take very long as it is a random event. This would provide a possible explanation to the long periodicity of $\mathrm{Ca}^{2+}$ oscillations as compared with the characteristic kinetic parameters of InsP $\mathrm{P}_{3} \mathrm{R}$ dynamics (see above).

Stochastic simulations taking spatial aspects into account are computationally extremely expensive, and, in fact, can only be performed when assuming drastic simplifications. In this framework, "threshold" models can easily be used to simulate spatial propagation of $\mathrm{Ca}^{2+}$ waves while taking stochastic effects into account. Threshold models, sometimes referred to "fire-diffuse-fire" models (Dawson et al. 1999; Thul et al. 2008) are based on the concept of excitability. The idea is that the cell consists on a set of $\mathrm{Ca}^{2+}$ releasing sites spaced by region of the cytoplasm where $\mathrm{Ca}^{2+}$ can only be diffused or be pumped back in the ER. At each releasing site, release will occur when $\mathrm{Ca}^{2+}$ exceeds a threshold. These simulations lead to saltatory waves that much resemble experimental observations. Interestingly, the value of the threshold may be chosen to fluctuate to approximate the stochastic gating of receptors (Coombes et al. 2004). These studies allowed investigation of how noise can shape the dynamics of intracellular $\mathrm{Ca}^{2+}$ waves. 
G. Dupont et al.
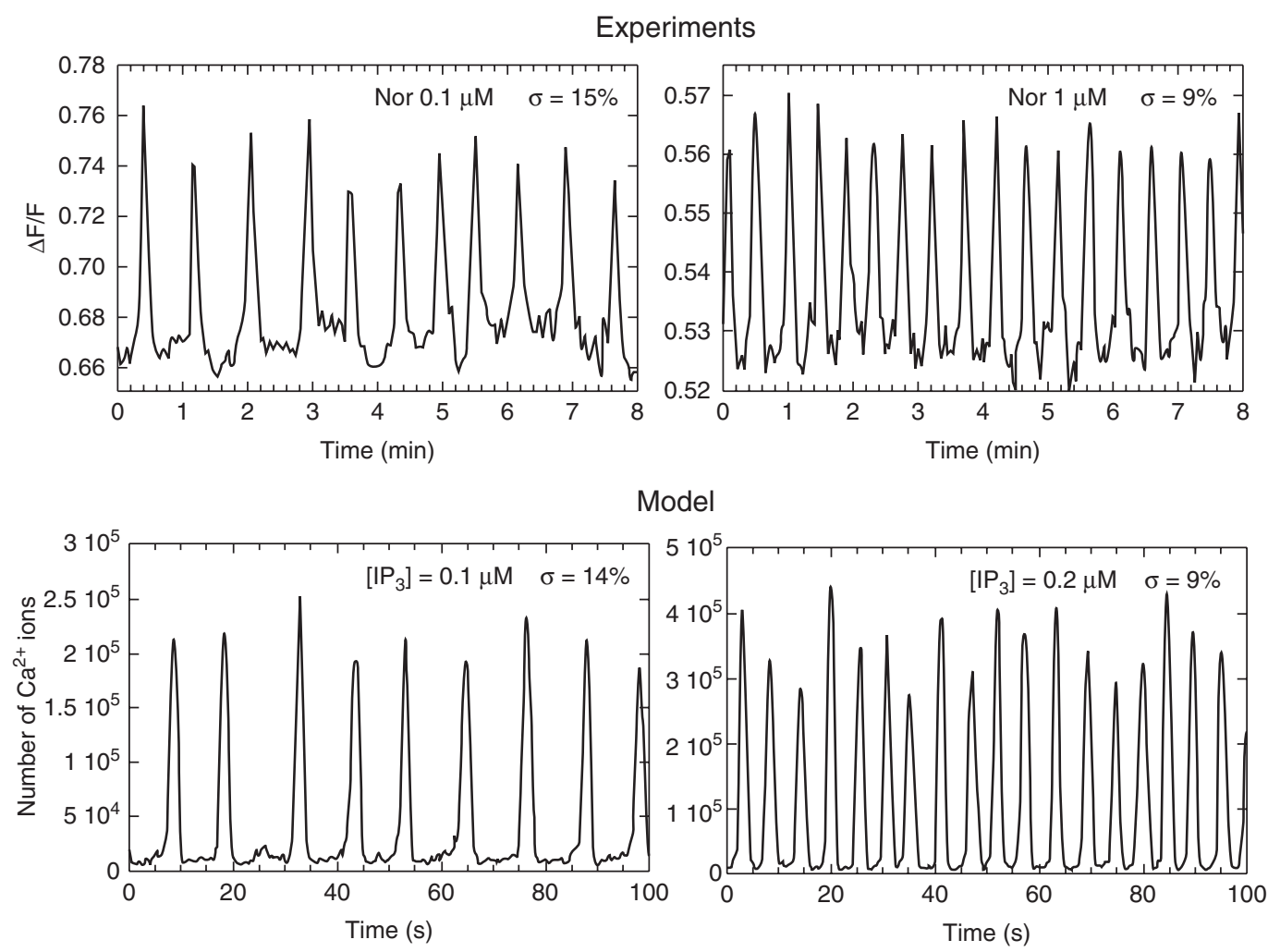

Figure 2. Comparison among $\mathrm{Ca}^{2+}$ oscillations observed in hepatocytes stimulated by noradrenaline (upper panels) and simulated by a stochastic Gillespie's algorithm taking into account realistic numbers of clusters of $\mathrm{Ins}_{3}$ receptors (lower panels). The model is based on the assumption that $\mathrm{Ca}^{2+}$ dynamics occur in a deterministic regime, in which fluctuations are visible because of the rather low number of clusters. Both in the model and in experiments, the variability decreases when the frequency increases. See Dupont et al. (2008) for details.

\section{Perspectives in Modeling $\mathrm{Ca}^{2+}$ Oscillations}

The detailed characteristics of $\mathrm{Ca}^{2+}$ oscillations vary considerably from one cell type to another. In view of the large number of physiological responses mediated by $\mathrm{Ca}^{2+}$, these changes may have significant implications. Modeling can be used to capture some detailed and quantitative understanding of this cell-to-cell variability. As an important factor, cells differ in their levels of expression of the three isoforms of the InsP $\mathrm{P}_{3} \mathrm{R}$. This can be considered in models by simulating three distinct populations of channels, differing in their regulatory properties by $\mathrm{Ca}^{2+}$ and $\mathrm{InsP}_{3}$. Simulations then point to the fact that modest changes in the regulatory properties of the InsP $\mathrm{P}_{3} \mathrm{R}$ can lead to significantly different oscillatory patterns, even if the bellshaped dependence of the open probability on the level of $\mathrm{Ca}^{2+}$ are only slightly altered (Dupont and Combettes 2006). In particular, the model shows that the robustness of $\mathrm{Ca}^{2+}$ oscillations is clearly isoform-dependent, with type 2 being the most robust. This agrees with experiments wherein the levels of expression of the various Ins $\mathrm{P}_{3} \mathrm{R}$ subtypes have been genetically modified in DT40, HeLa, and COS-7 cells (Miyakawa et al. 1999; Hattori et al. 2004).

Surprisingly, many factors that are known to alter $\mathrm{Ca}^{2+}$ oscillations have not yet been extensively considered in models. For example, despite the large number of experimental studies devoted to the mechanism of $\mathrm{Ca}^{2+}$ entry (Putney and Bird 2008), most models for 
$\mathrm{Ca}^{2+}$ oscillations in nonexcitable cells consider a closed system where $\mathrm{Ca}^{2+}$ exchanges are limited to fluxes between the cytoplasm and the ER. Mitochondrial $\mathrm{Ca}^{2+}$ handling is also known to alter cellular $\mathrm{Ca}^{2+}$ signals in the cytoplasm (Halestrap 2009). Although some models have been developed to explain the pumping and releasing properties of suspensions of mitochondria (Selivanov et al. 1998), their implication in intact cells have rarely been investigated theoretically (Marhl et al. 1998; Fall and Keizer 2001). As a last example, much remains to be performed in the field of intercellular $\mathrm{Ca}^{2+}$ wave propagation in which the oscillatory signal is coordinated at the organ level. Although quite well understood at the level of the communication among a few cells (Sneyd et al. 1995; Dupont et al. 2000; Hofer et al. 2002; Gracheva and Gunton 2003), signal transmission on large populations of cells remains puzzling. Such communication has vital implications as in the case of liver regeneration (Nicou et al. 2007) or in the brain (Haas et al. 2006).

\section{INTERPLAY BETWEEN Ca ${ }^{2+}$ ENTRY AND $\mathrm{Ca}^{2+}$ RELEASE DURING $\mathrm{Ca}^{2+}$ OSCILLATIONS}

The release of $\mathrm{Ca}^{2+}$ from intracellular stores, whether by maximal or submaximal concentrations of agonists, is generally accompanied by an increased influx of $\mathrm{Ca}^{2+}$ across the plasma membrane (Putney et al. 1981). $\mathrm{Ca}^{2+}$ oscillations run down in the absence of extracellular $\mathrm{Ca}^{2+}$, suggesting a requirement for $\mathrm{Ca}^{2+}$ influx for their maintenance. However, at least in some nonexcitable cells, $\mathrm{Ca}^{2+}$ influx does not appear to be required to drive the oscillations. This can be shown by use of a technique that we have termed "lanthanide insulation" (Bird and Putney 2005). Relatively high concentrations $(\mathrm{mM})$ of lanthanides $\left(\mathrm{Gd}^{3+}, \mathrm{La}^{3+}\right)$ effectively inhibit both $\mathrm{Ca}^{2+}$ influx and $\mathrm{Ca}^{2+}$ extrusion at the plasma membrane (Van Breemen et al. 1972). Thus, in the presence of these high lanthanide concentrations, $\left[\mathrm{Ca}^{2+}\right]$ i signals are sustained, even in the absence of extracellular $\mathrm{Ca}^{2+}$ (Kwan et al. 1990; Bird and Putney 2005). This is also true for $\mathrm{Ca}^{2+}$ oscillations; lanthanide insulation permits sustained oscillations in the absence of extracellular $\mathrm{Ca}^{2+}$ (Sneyd et al. 2004; Bird and Putney 2005; Di Capite et al. 2009) (Fig. 3). This will be important in considering arguments about the physiological function of $\mathrm{Ca}^{2+}$ oscillations in a subsequent section.

In most cell types, especially in nonexcitable cells, release of store $\mathrm{Ca}^{2+}$ activates influx through store-operated $\mathrm{Ca}^{2+}$ (SOC) channels (Putney 1986; Parekh and Putney 2005). The most extensively studied and characterized
A

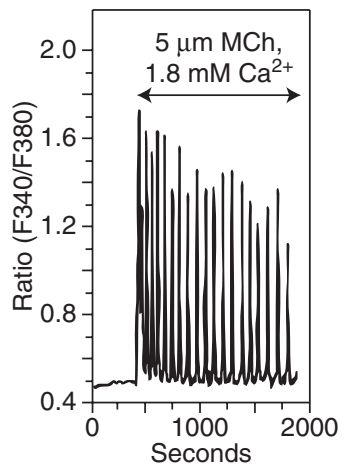

B

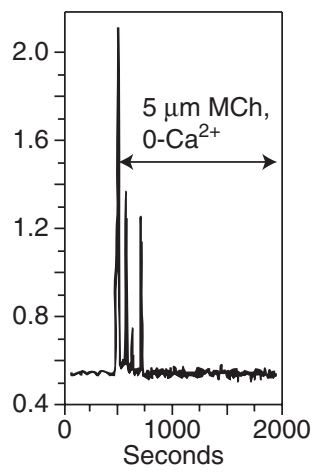

C

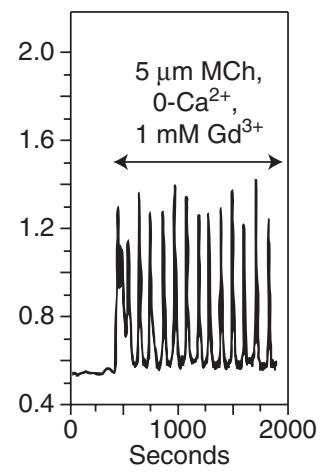

Figure 3. Lanthanide insulation renders $\mathrm{Ca}^{2+}$ oscillations independent of extracellular $\mathrm{Ca}^{2+}$. (A) $5 \mu \mathrm{M}$ methacholine (MCh) induces sustained oscillations in a HEK293 cell. (B) In the absence of extracellular $\mathrm{Ca}^{2+}$, oscillations are not sustained. $(C)$ In the presence of $1 \mathrm{mM} \mathrm{Gd}^{3+}$, oscillations are sustained, even in the absence of extracellular $\mathrm{Ca}^{2+}$. These panels illustrate responses of single cells. The statistical evaluation of multiple cells analyzed with this procedure is summarized in Bird and Putney (2005). 
G. Dupont et al.

SOC current is the calcium-release-activatedcalcium current $\left(I_{\text {crac }}\right)$ (Hoth and Penner 1992; Parekh and Putney 2005). The channels underlying $I_{\text {crac }}$ have thus been referred to as CRAC channels, which may represent a specific type of SOC channel. The properties of CRAC channels include high $\mathrm{Ca}^{2+}$ selectivity and very low single channel conductance (Parekh and Putney 2005). However, both store-operated $\mathrm{Ca}^{2+}$ fluxes (generally measured by use of fluorescent $\mathrm{Ca}^{2+}$ indicators) as well as $I_{\text {crac }}$ have been most commonly investigated utilizing strategies that produce extensive, nearly complete depletion of endoplasmic $\mathrm{Ca}^{2+}$ stores, rather than under conditions of modest depletion as expected during $\mathrm{Ca}^{2+}$ oscillations. Indeed, the nature of the $\mathrm{Ca}^{2+}$ influx mechanism that supports $\mathrm{Ca}^{2+}$ oscillations has been the subject of some debate. Shuttleworth suggested that, rather than store operated channels, channels activated by arachidonic acid is necessary to maintain oscillations (Shuttleworth 1999). Such channels clearly exist and the $\mathrm{Ca}^{2+}$-selective current underlying arachidonic acid-activated entry, termed $I_{\text {arc }}$, has been well characterized (Shuttleworth et al. 2004). The physiological function of these channels is less clear, however. The idea that ARC channels are involved in $\mathrm{Ca}^{2+}$ entry was based largely on pharmacological evidence utilizing a phospholipase $\mathrm{A}_{2}$ inhibitor of questionable specificity (Bird and Putney 2005). On the other hand, use of $\mathrm{Gd}^{3+}$ (at low $\mu \mathrm{M}$ concentrations) and 2aminoethyldiphenyl borate (2APB), two known inhibitors of SOC channels, caused rundown of muscarinic receptor-induced $\mathrm{Ca}^{2+}$ oscillations in HEK293 cells in a manner indistinguishable from that seen by simple omission of extracellular $\mathrm{Ca}^{2+}$ (Bird and Putney 2005).

\section{Store-Operated $\mathrm{Ca}^{2+}$ Channels}

The major molecular components of the SOC entry pathway are STIM (STIM1 and 2) and Orai (Orai1, 2, and 3) (Frischauf et al. 2008). STIM1 and 2 reside in the endoplasmic reticulum where they function as sensors of endoplasmic reticulum $\mathrm{Ca}^{2+}$ content. Both proteins have a $\mathrm{Ca}^{2+}$-binding EF-hand motif in the $\mathrm{N}$ - terminus, directed toward the lumen of the endoplasmic reticulum (Dziadek and Johnstone 2007). A drop in endoplasmic reticulum $\mathrm{Ca}^{2+}$ content causes $\mathrm{Ca}^{2+}$ to dissociate from STIM1. This results in a conformational change (Zheng et al. 2008) that permits self-association of STIM molecules (Liou et al. 2007). In this poorly defined aggregated state, STIM localizes to near plasma membrane junctions (Orci et al. 2009) where it appears to be capable of directly interacting with Orai subunits of the storeoperated channels (Park et al. 2009). There are also a number of publications implicating members of the TRPC (canonical transient receptor potential) cation channel family as candidate SOC channels (Birnbaumer et al. 2000; Rosado and Sage 2000; Abeele et al. 2003; Albert and Large 2003; Beech 2005; Ambudkar 2006; Huang et al. 2006). However, some of the published findings implicating TRPCs as SOC channels could not be reproduced (DeHaven et al. 2009). Nonetheless, it is clear that activation of phospholipase $\mathrm{C}$ activates $\mathrm{Ca}^{2+}$-permeable TRPC channels (Vazquez et al. 2004) and it is thus possible that they will play a role in $\mathrm{Ca}^{2+}$ oscillations. In the HEK293 cell model, and consistent with the pharmacological data, knockdown by RNAi of either STIM1 or Orail in HEK293 essentially completely abrogated $\mathrm{Ca}^{2+}$ oscillations (Wedel et al. 2007). However, these proteins are also thought to play a role in the arachidonic acid pathway (Shuttleworth et al. 2007; Mignen et al. 2008). The role of STIM1 in ARC channel activation is quite different from that for SOC channels. ARC channels require STIM1 in the plasma membrane (Shuttleworth et al. 2004), whereas for the SOC channels, STIM1 is only necessary in the endoplasmic reticulum (Mercer et al. 2006). Thus, it is significant that loss of sustained oscillations following RNAi knockdown of STIM1 could be reversed by expression of a STIM1 construct modified to preclude its translocation to the plasma membrane (Wedel et al. 2007). In aggregate, the evidence convincingly supports the view that in the HEK293 cell model, the $\mathrm{Ca}^{2+}$ entry underlying $\mathrm{Ca}^{2+}$ oscillations is store-operated $\mathrm{Ca}^{2+}$ entry (Putney and Bird 2008). 
During the process of $\mathrm{Ca}^{2+}$ oscillations, the quantity of $\mathrm{Ca}^{2+}$ discharged with each spike can be quite small (Bird and Putney 2005). Thus, it is presumed that when even a small amount of $\mathrm{Ca}^{2+}$ is lost from the endoplasmic reticulum, STIM is activated and causes Orai channels to open sufficiently to maintain intracellular $\mathrm{Ca}^{2+}$ stores. In this context, it is important to consider the sensitivities of the two STIM proteins, STIM1 and STIM2, to $\mathrm{Ca}^{2+}$ store depletion. When stores are gradually depleted of $\mathrm{Ca}^{2+}$, STIM2 begins to move to the plasma membrane before STIM1 (Brandman et al. 2007; Bird et al. 2009). In addition, overexpression of STIM2, but not STIM1, results in constitutive $\mathrm{Ca}^{2+}$ entry (Soboloff et al. 2006b; Brandman et al. 2007; Parvez et al. 2008; Bird et al. 2009). These findings suggest that STIM2 is responsive to a very small degree of $\mathrm{Ca}^{2+}$ store depletion and is apparently partially active under resting conditions. STIM1 on the otherhand, appears to require a substantial degree of $\mathrm{Ca}^{2+}$ store depletion before it can be activated. It was thus somewhat surprising that when the relative roles of STIM1 and STIM2 in $\mathrm{Ca}^{2+}$ oscillations were assessed, it was STIM1 rather than STIM2 that was required (Bird et al. 2009).

In the HEK293 cell model used for these studies, Western analysis clearly showed the presence of STIM2 in quantities similar to those for STIM1 (Bird et al. 2009). Why then did the STIM2 play no significant role in supporting the $\mathrm{Ca}^{2+}$ oscillations? The answer is probably that STIM2 is a very inefficient activator of Orai channels. When both STIM2 and STIM1 are overexpressed in cells, STIM2 appears to act as an inhibitor of STIM1 (Soboloff et al. 2006a), as would be expected if its interaction with Orai channels is relatively ineffective. This should not be surprising if in fact STIM2 is already partially active under basal conditions. Nonetheless, when STIM2 is overexpressed in cells, along with overexpressed Orai1, large STIM2-dependent $\mathrm{Ca}^{2+}$ influx signals can be observed (Parvez et al. 2008). However, the stoichiometry of STIM2 and Orail is unknown in this condition, such that the relative efficiency of STIM2 as an activator of Orail cannot be evaluated. To compare the efficiency of STIM1 and STIM2 under conditions of similar stoichiometry with Orail, the EF-hand mutants of STIM1 and STIM2 were transiently transfected into HEK293 cells, but without transfecting the cells with additional Orail (Bird et al. 2009). In this condition, STIM1 or STIM2 is presumed to be in considerable excess relative to the native Orail. The EF-hand mutants of STIM1 and 2 are constitutively active, precluding the need for store depletion and thereby eliminating any contribution from endogenous STIM proteins. The result of this experiment was a robust constitutive entry of $\mathrm{Ca}^{2+}$ in the cells expressing the EF-hand mutant of STIM1, but no constitutive entry in cells expressing the EF-hand mutant of STIM2, consistent with the idea that STIM2 is a much poorer activator of Orail channels (Bird et al. 2009).

Thus, at least in HEK293 cells, the $\mathrm{Ca}^{2+}$ entry that supports $\mathrm{Ca}^{2+}$ oscillations is triggered by STIM1 interacting with and activating plasma membrane Orail channels. This suggests that during the oscillations, the endoplasmic reticulum $\mathrm{Ca}^{2+}$ concentration falls into the range in which STIM1 is activated. This presumably occurs in a small domain of the endoplasmic reticulum situated in close proximity to the plasma membrane, and this is consistent with earlier suggestions that there is a subcompartment of the endoplasmic reticulum that is specifically involved in regulating plasma membrane SOC channels (Ribeiro and Putney 1996; Parekh et al. 1997; Orci et al. 2009).

\section{Physiological Relevance of SOC Channels for Cellular Signaling}

The aforementioned scenario is relevant to a long standing question in the $\mathrm{Ca}^{2+}$ signaling field: what is the functional significance of $\mathrm{Ca}^{2+}$ oscillations? The generally accepted answer to this question is that $\mathrm{Ca}^{2+}$ oscillations provide a digital signal to downstream effectors and this is advantageous at low levels of signaling because of the high signal-to-noise discrimination of digital information encoding (Meyer et al. 1992; Thomas et al. 1996; Berridge 1997; Dolmetsch et al. 1998). Implicit in this 
G. Dupont et al.

conclusion is that the effectors downstream of the $\mathrm{Ca}^{2+}$ oscillations must have at least moderately elevated thresholds for responding, providing high signal-to-noise and preventing any ambiguity in distinguishing a true signal from random fluctuations. One well established target of $\mathrm{Ca}^{2+}$ released from the endoplasmic reticulum through InsP $_{3}$ receptors is the mitochondria (Rizzuto et al. 1992; Hajnóczky et al. 1995; Rizzuto et al. 1998; Rizzuto and Pozzan 2006). The mitochondrial uniporter, responsible for accumulation of $\mathrm{Ca}^{2+}$, has a sensitivity to $\mathrm{Ca}^{2+}$ well above the physiological range of global $\mathrm{Ca}^{2+}$ changes (Blaustein et al. 1977; Burgess et al. 1983). Yet, the positioning of uptake sites close to sites of release, provides a kind of intracellular synapse assuring that bursts of local $\mathrm{Ca}^{2+}$ release are read by mitochondria, resulting in the activation of important $\mathrm{Ca}^{2+}$-regulated mitochondrial enzymes (Csordas et al. 2006).

But in addition to mitochondrial function, $\mathrm{Ca}^{2+}$ signaling, most commonly through some kind of oscillatory mechanism, regulates a large variety of downstream effectors. There is evidence that some of these are tightly coupled to $\mathrm{Ca}^{2+}$ entering through SOC channels. One of the most extensively documented and investigated examples is the requirement for $\mathrm{Ca}^{2+}$ influx through CRAC channels for activation of calcineurin/NFAT signaling in T-lymphocytes (Oh-Hora 2009). Because activation of this pathway is known to require $\mathrm{Ca}^{2+}$ elevation for hours, it is implicitly understood that $\mathrm{Ca}^{2+}$ influx is necessary to maintain signaling over such a prolonged period. And it is clear that signaling fails in the absence of $\mathrm{Ca}^{2+}$ influx through CRAC channels (Feske et al. 2006). However, it is not clear whether $\mathrm{Ca}^{2+}$ entry provides the $\mathrm{Ca}^{2+}$ directly responsible for activation of calcineurin/NFAT signaling, or rather serves to maintain intracellular stores such that continued release through $\mathrm{Ins}_{3}$ receptors can activate the pathway. There are a few studies that have experimentally shown the specific requirement of $\mathrm{Ca}^{2+}$ entering through SOC channels. Perhaps the first such $\mathrm{Ca}^{2+}$-sensitive effectors found to be closely coupled to SOC entry were some of the $\mathrm{Ca}^{2+}$-regulated adenylyl cyclases (Cooper et al. 1994). Another example elegantly showed in a study from Parekh's laboratory is cytoplasmic phospholipase A2 (cPLA2) (Chang et al. 2006), an important $\mathrm{Ca}^{2+}$-regulated effector in many cells in the immune system and elsewhere. In the mast cell line RBL-1, $\mathrm{Ca}^{2+}$ store depletion activates plasma membrane CRAC channels, which leads to cPLA2 activation. The activation of cPLA2 was mediated by extracellular signal regulated kinases (ERKs). The ERKs are apparently activated by protein kinase $C \alpha$, which is the likely target of $\mathrm{Ca}^{2+}$ entering through the CRAC channels (Chang et al. 2006). In this same study, it was shown that activation of the early gene, c-fos, was also closely coupled to $\mathrm{Ca}^{2+}$ entering through CRAC channels but was not dependent on ERK activation. The dependence of these responses specifically on $\mathrm{Ca}^{2+}$ entry was shown by use of the "lanthanide insulation" technique described above (Bird and Putney 2006). Thus, in the absence of extracellular $\mathrm{Ca}^{2+}$ but in the presence of high concentrations of lanthanides, depletion of $\mathrm{Ca}^{2+}$ stores with thapsigargin induced large sustained elevations of cytoplasmic $\mathrm{Ca}^{2+}$, yet cPLA2 was not induced (Chang et al. 2008). This result indicated that the global rise in intracellular $\mathrm{Ca}^{2+}$ was not important for activation of gene expression, rather it was the $\mathrm{Ca}^{2+}$ specifically entering through the plasma membrane CRAC channels.

The above-discussed examples all used supramaximal stimuli to produce large, sustained increases in $\mathrm{Ca}^{2+}$ influx. In one study, the role of $\mathrm{Ca}^{2+}$ influx in activating gene expression during $\mathrm{Ca}^{2+}$ oscillations was investigated. Di Capite et al. (2009), following on the earlier demonstration of c-fos induction by SOC entry, examined the activation of $\mathrm{c}$-fos expression in response to $\mathrm{Ca}^{2+}$ oscillations induced by modest concentrations of leukotriene $\mathrm{C} 4$ applied to RBL-1 cells. By use of the "lanthanide insulation" technique, oscillations were obtained in the absence of extracellular $\mathrm{Ca}^{2+}$, but in the presence of high lanthanum and these oscillations were sustained and indistinguishable from those in the presence of extracellular $\mathrm{Ca}^{2+}$. However, c-fos was only induced in the presence of extracellular $\mathrm{Ca}^{2+}$ when $\mathrm{Ca}^{2+}$ influx 
could occur through the CRAC channels. Thus, it may be concluded that in this instance the global rise in $\mathrm{Ca}^{2+}$ associated with $\mathrm{Ca}^{2+}$ oscillations is irrelevant for activation of the pathway that leads to $\mathrm{c}-f o s$ activation. Rather, $\mathrm{Ca}^{2+}$ entering through the plasma membrane CRAC channels couples specifically to the initial steps in this signaling pathway (Di Capite et al. 2009).

The generality of this scenario remains to be shown. Indeed, gene expression can clearly be turned on in some experimental situations by elevations in global $\mathrm{Ca}^{2+}$ (Dolmetsch et al. 1998). Also, it is clear that $\mathrm{Ca}^{2+}$ released by $\mathrm{IP}_{3}$ Rs can also be coupled to specific signaling pathways. The clearest such example is the regulation of carbohydrate and energy metabolism through close $\mathrm{IP}_{3} \mathrm{R}$-mitochondrial coupling (Rizzuto and Pozzan 2006). Nonetheless, a specialized signaling function of SOC channels fits nicely with the previously related story of $\mathrm{Ca}^{2+}$ entry signaling by STIM1 during oscillations. If in fact $\mathrm{Ca}^{2+}$ entering through SOC channels can provide the key signal for downstream pathways, then it is not so surprising that STIM1 and not STIM2, provides the link between the oscillations and the SOC channels. It has for some time been supposed that the digital nature of cytoplasmic $\mathrm{Ca}^{2+}$ oscillations provides a high signal-to-noise signal input to downstream $\mathrm{Ca}^{2+}$-regulated effectors, obviating the possibility of small unintentional signaling fluctuations. Because STIM1 requires a threshold of $\mathrm{Ca}^{2+}$ store depletion for activation, this then means that a $\mathrm{Ca}^{2+}$ oscillation, producing a transient but apparently substantial drop in ER luminal $\mathrm{Ca}^{2+}$, will produce a transient activation of STIM1 and an incremental activation of the SOC channel. Small fluctuations in ER $\mathrm{Ca}^{2+}$ will not affect STIM1, preventing unintentional activation of SOC channels. However, small fluctuations in $\mathrm{ER} \mathrm{Ca}^{2+}$ can activate STIM2 which will produce small activation of SOC channels sufficient to keep stores filled, but insufficient to activate downstream effectors. With this reasoning, the rise in cytoplasmic $\mathrm{Ca}^{2+}$ that is experimentally observed during $\mathrm{Ca}^{2+}$ oscillations is not directly relevant to the signaling pathway, except insofar as it reflects the digital drop in ER $\mathrm{Ca}^{2+}$ and subsequent activation of SOC channels. By similar reasoning, one would speculate that in some cell types, or in response to specific stimuli, SOC channels do not function to maintain intracellular stores so that $\mathrm{InsP}_{3}$-induced release can activate downstream signaling; rather one might conclude that during $\mathrm{Ca}^{2+}$ oscillations, $\mathrm{Ins}_{3}$-induced release functions to drive $\mathrm{ER}$ $\mathrm{Ca}^{2+}$ into the STIM1 sensing range, resulting in SOC channel opening and activation of downstream signaling. This would require not only spatial organization of the immediate downstream $\mathrm{Ca}^{2+}$ sensor, but also some degree of localized endoplasmic reticulum depletion because during a single $\mathrm{Ca}^{2+}$ oscillation, the extent of global endoplasmic reticulum depletion is quite small.

\section{CONCLUSIONS}

In this review, we have analyzed two major aspects of $\mathrm{Ca}^{2+}$ oscillations. First, we show how the use of computational models of $\mathrm{Ca}^{2+}$ oscillations can lead to a number of important conclusions about mechanisms of generation of oscillations. Models indeed allow us to conceptualize and quantify intuitive reasoning, which is particularly useful for oscillatory phenomena. We also emphasize the need for specific modeling approaches depending on the cell type, the stimulus and the specific aspect of $\mathrm{Ca}^{2+}$ signaling of interest. Second, we review recent findings indicating an important role for storeoperated $\mathrm{Ca}^{2+}$ entry in $\mathrm{Ca}^{2+}$ oscillations and particularly in the physiological mechanism by which the digital information contained in the oscillations is linked to downstream effectors. Hopefully, continued research in these two areas will further increase our understanding of the mechanisms and meaning of the fascinating phenomena, $\mathrm{Ca}^{2+}$ oscillations.

\section{ACKNOWLEDGMENTS}

Work discussed in this review originating in the laboratory of JP and GB was supported by the Intramural Program, National Institutes of Health. GD is Maitre de Recherche at the Belgian FNRS. GD acknowledges support from 


\section{G. Dupont et al.}

the Fonds de la Recherche Scientifique Médicale (grant No. 3.4636.04), the European Union through the Network of Excellence BioSim (Contract No. LSHB-CT-2004-005137), and the Belgian Program on Interuniversity Attraction Poles, initiated by the Belgian Federal Science Policy Office, project No.P6/25 (BIOMAGNET). LC acknowledges support from ANR (RPV07094LSA) and PNR in Hepatogastroenterology. LC is supported by an interface contract between Inserm and AP-HP (LE KremlinBicetre Hospital). This work was supported by a PHC Tournesol 2009 program.

\section{REFERENCES}

Abeele FV, Shuba Y, Roudbaraki M, Lemonnier L, Vanoverberghe K, Mariot P, Skryma R, Prevarskaya N. 2003. Store-operated $\mathrm{Ca}^{2+}$ channels in prostate cancer epithelial cells: function, regulation, and role in carcinogenesis. Cell Calcium 33: 357-373.

Albert AP, Large WA. 2003. Store-operated $\mathrm{Ca}^{2+}$-permeable non-selective cation channels in smooth muscle cells. Cell Calcium 33: 345-356.

Allen V, Swigart P, Cheung R, Cockcroft S, Katan M. 1997. Regulation of inositol lipid-specific phospholipase $c \delta$ by changes in $\mathrm{Ca}^{2+}$ ion concentrations. Biochem J 327: $545-552$.

Ambudkar IS. 2006. $\mathrm{Ca}^{2+}$ signaling microdomains: Platforms for the assembly and regulation of TRPC channels. Trends Pharmacol Sci 27: 25-32.

Atri A, Amundson J, Clapham D, Sneyd J. 1993. A singlepool model for intracellular calcium oscillations and waves in the Xenopus laevis oocyte. Biophys J 65: 17271739.

Beech DJ. 2005. Emerging functions of 10 types of TRP cationic channel in vascular smooth muscle. Clin Exp Pharmacol Physiol 32: 597-603.

Berridge MJ. 1990. Calcium oscillations. J Biol Chem 265: 9583-9586.

Berridge MJ. 1991. Cytoplasmic calcium oscillations: A two pool model. Cell Calcium 12: 63-72.

Berridge MJ. 1997. Elementary and global aspects of calcium signalling. J Physiol (Lond) 499: 291-306.

Berridge MJ, Galione A. 1988. Cytosolic calcium oscillators. FASEB J 2: 3074-3082.

Bezprozvanny I. 1994. Theoretical analysis of calcium wave propagation based on inositol (1,4,5)-trisphosphate $\left(\mathrm{InsP}_{3}\right)$ receptor functional properties. Cell Calcium 16: 151-166.

Bezprozvanny I, Watras J, Ehrlich BE. 1991. Bell-shaped calcium-response curves of Ins $(1,4,5) \mathrm{P}_{3}$ and calciumgated channels from endoplasmic reticulum of cerebellum. Nature 351: 751-754.

Bird GS, Putney JW. 2005. Capacitative calcium entry supports calcium oscillations in human embryonic kidney cells. J Physiol 562: 697-706.
Bird GS, Putney JW. 2006. Fluorescent indicators-facts and artifacts. In Calcium Signaling (ed. JW Putney), pp. 51-84. CRC Press, Boca Raton.

Bird GS, Hwang SY, Smyth JT, Fukushima M, Boyles RR, Putney JW Jr. 2009. STIM1 is a calcium sensor specialized for digital signaling. Curr Biol 19: 1724-1729.

Birnbaumer L, Boulay G, Brown D, Jiang M, Dietrich A, Mikoshiba K, Zhu X, Qin N. 2000. Mechanism of capacitative $\mathrm{Ca}^{2+}$ entry (CCE): interaction between IP3 receptor and TRP links the internal calcium storage compartment to plasma membrane CCE channels. Recent Prog Horm Res 55: 127-161.

Blaustein MP, Kendrick NC, Fried RC, Ratzlaff RW. 1977. Calcium metabolism at the mammalian presynaptic nerve terminal: Lessons from the synaptsome. In Society for Neuroscience Symposia, Vol. II. Approaches to the Cell Biology of Neurons (ed. MW Cowan, JA Ferrendelli), pp. 172-194. Society for Neuroscience, Bethesda, MD.

Bohr DF. 1973. Vascular smooth muscle updated. Circ Res 32: $665-672$.

Bootman MD, Berridge MJ, Roderick HL. 2002. Calcium signalling: more messengers, more channels, more complexity. Curr Biol 12: R563-R565.

Brandman O, Liou J, Park WS, Meyer T. 2007. STIM2 is a feedback regulator that stabilizes basal cytosolic and endoplasmic reticulum $\mathrm{Ca}^{(2+)}$ levels. Cell 131: 1327-1339.

Burgess GM, McKinney JS, Fabiato A, Leslie BA, Putney JW. 1983. Calcium pools in saponin-permeabilized guineapig hepatocytes. J Biol Chem 258: 15336-15345.

Chang WC, Capite JDi, Singaravelu K, Nelson C, Halse V, Parekh AB. 2008. Local $\mathrm{Ca}^{2+}$ Influx through $\mathrm{Ca}^{2+}$ Release-activated $\mathrm{Ca}^{2+}$ (CRAC) Channels Stimulates Production of an Intracellular Messenger and an Intercellular Pro-inflammatory Signal. J Biol Chem 283: 46224631.

Chang WC, Nelson C, Parekh AB. 2006. $\mathrm{Ca}^{2+}$ influx through CRAC channels activates cytosolic phospholipase A2, leukotriene $\mathrm{C} 4$ secretion, and expression of $\mathrm{c}-$ fos through ERK-dependent and -independent pathways in mast cells. FASEB J 20: 2381-2383.

Chatton JY, Cao Y, Stucki JW. 1998. Perturbation of myo-inositol-1,4,5-trisphosphate levels during agonistinduced $\mathrm{Ca}^{2+}$ oscillations. Biophys J 74: 523-531.

Combettes LHannaert-Merah Z, Coquil J-F, Rousseau C, Claret M, Swillens S, Champeil P. 1994. Rapid filtration studies of the effect of cytosolic $\mathrm{Ca}^{2+}$ on inositol 1,4,5-trisphosphate-induced ${ }^{45} \mathrm{Ca}^{2+}$ release from cerebellar microsomes. J Biol Chem 269: 17561-17571.

Coombes S, Hinch R, Timofeeva Y. 2004. Receptors, sparks, and waves in a fire-diffuse-fire framework for calcium release. Prog Biophys Mol Biol 85: 197-216.

Cooper DMF, Yoshimura M, Zhang Y, Chiono M, Mahey R. 1994. Capacitative $\mathrm{Ca}^{2+}$ entry regulates $\mathrm{Ca}^{2+}$-sensitive adenylyl cyclases. Biochem J 297: 437-440.

Csordas G, Renken C, Varnai P, Walter L, Weaver D, Buttle KF, Balla T, Mannella CA, Hajnoczky G. 2006. Structural and functional features and significance of the physical linkage between ER and mitochondria. J Cell Biol 174: 915-921. 
Cuthbertson KS, Chay TR. 1991. Modeling receptorcontrolled intracellular calcium oscillators. Cell Calcium 12: $97-109$.

Cuthbertson KSR, Cobbold PH. 1991. Oscillations in cell calcium (Collected papers and reviews). Cell Calcium 12: $61-268$.

Dawson SP, Keizer J, Pearson JE. 1999. Fire-diffuse-fire model of dynamics of intracellular calcium waves. Proc Natl Acad Sci 96: 6060-6063.

DeHaven WI, Jones BF, Petranka JG, Smyth JT, Tomita T, Bird GS, Putney JW. 2009. TRPC channels function independently of STIM1 and Orail. J Physiol 587: 2275-2298.

De Pitta M, Goldberg M, Volman V, Berry H, Ben-Jacob E. 2009. Glutamate regulation of calcium and IP(3) oscillating and pulsating dynamics in astrocytes. J Biol Phys 35: 383-411.

De Young GW, Keizer J. 1992. A single-pool inositol 1,4,5trisphosphate-receptor-based model for agonist-stimulated oscillations in $\mathrm{Ca}^{2+}$ concentration. Proc Nat Acad Sci 89: 9895-9899.

DiCapite J, Ng SW, Parekh AB. 2009. Decoding of cytoplasmic $\mathrm{Ca}^{(2+)}$ oscillations through the spatial signature drives gene expression. Curr Biol 19: 853-858.

Dolmetsch RE, Xu KL, Lewis RS. 1998. Calcium oscillations increase the efficiency and specificity of gene expression. Nature 392: 933-936.

Dupont G, Goldbeter A. 1993. One-pool model for $\mathrm{Ca}^{2+}$ oscillations involving $\mathrm{Ca}^{2+}$ and inositol 1,4,5-trisphosphate as co-agonists for $\mathrm{Ca}^{2+}$ release. Cell Calcium 14: 311-322.

Dupont G, Swillens S. 1996. Quantal release, incremental detection, and long-period $\mathrm{Ca}^{2+}$ oscillations in a model based on regulatory $\mathrm{Ca}^{2+}$-binding sites along the permeation pathway. Biophys J 71: 1714-1722.

Dupont G, Erneux C. 1997. Simulations of the effects of inositol 1,4,5-trisphosphate 3-kinase and 5-phosphatase activities on $\mathrm{Ca}^{2+}$ oscillations. Cell Calcium 22:321-331.

Dupont G, Dumollard R. 2004. Simulation of calcium waves in ascidian eggs: insights into the origin of the pacemaker sites and the possible nature of the sperm factor. J Cell Sci 117: $4313-4323$

Dupont G, Combettes L. 2006. Modeling the effect of specific inositol 1,4,5-trisphosphate receptor isoforms on cellular $\mathrm{Ca}^{2+}$ signals. Biol Cell 98: 171-182.

Dupont G, Combettes L. 2009. What can we learn from the irregularity of $\mathrm{Ca}^{2+}$ oscillations?. Chaos 19: 037112.

Dupont G, Combettes L, Leybaert L. 2007. Calcium dynamics: spatio-temporal organization from the subcellular to the organ level. Int Rev Cytol 261: 193-245.

Dupont G, Bou-Lovergne A, Combettes L. 2008. Stochastic Aspects of Oscillatory $\mathrm{Ca}^{2+}$ Dynamics in Hepatocytes. Biophys J 95: 2193-2202.

Dupont G, Koukoui O, Clair C, Erneux C, Swillens S, Combettes L. 2003. $\mathrm{Ca}^{2+}$ oscillations in hepatocytes do not require the modulation of $\operatorname{InsP}_{3}$ 3-kinase activity by $\mathrm{Ca}^{2+}$. FEBS Lett 534: 101-105.

Dupont G, Tordjmann T, Clair C, Swillens S, Claret M, Combettes L. 2000. Mechanism of receptor-oriented intercellular calcium wave propagation in hepatocytes. FASEB J 14: 279-289.
Dziadek MA, Johnstone LS. 2007. Biochemical properties and cellular localisation of STIM proteins. Cell Calcium 42: $123-132$.

Fabiato A. 1983. Calcium-induced release of calcium from the cardiac sarcoplasmic reticulum. Am J Physiol 245: C1-C4.

Falcke M. 2004. Reading the patterns in living cells-the physics of $\mathrm{Ca}^{2+}$ signaling. Adv Physics 53: 255-440.

Fall CP, Keizer JE. 2001. Mitochondrial modulation of intracellular $\mathrm{Ca}^{2+}$ signaling. J Theor Biol 210: 151-165.

Feske S, Gwack Y, Prakriya M, Srikanth S, Puppel SH, Tanasa B, Hogan PG, Lewis RS, Daly M, Rao A. 2006. A mutation in Orail causes immune deficiency by abrogating CRAC channel function. Nature 441: 179-185.

Finch EA, Turner TJ, Goldin SM. 1991. Calcium as a coagonist of inositol 1,4,5-trisphosphate-induced calcium release. Science 252: 443-446.

Fioretti B, Franciolini F, Catacuzzeno L. 2005. A model of intracellular $\mathrm{Ca}^{2+}$ oscillations based on the activity of the intermediate-conductance $\mathrm{Ca}^{2+}$-activated $\mathrm{K}^{+}$channels. Biophys Chem 113: 17-23.

Fraiman D, Pando B, Dargan S, Parker I, Dawson SP. 2006. Analysis of puff dynamics in oocytes: interdependence of puff amplitude and interpuff interval. Biophys $J$ 90: 3897-3907.

Frischauf I, Schindl R, Derler I, Bergsmann J, Fahrner M, Romanin C. 2008. The STIM/Orai coupling machinery. Channels (Austin) 2: 261-268.

Goldbeter A. 2008. Biological rhythms: clocks for all times. Curr Biol 18: R751-R753.

Goldbeter A, Dupont G, Berridge MJ. 1990. Minimal model for signal-induced $\mathrm{Ca}^{2+}$ oscillations and for their frequency encoding through protein phosphorylation. Proc Nat Acad Sci 87: 1461-1465.

Gracheva ME, Gunton JD. 2003. Intercellular communication via intracellular calcium oscillations. J Theor Biol 221: 513-518.

Haas B, Schipke CG, Peters O, Sohl G, Willecke K, Kettenmann H. 2006. Activity-dependent ATP-waves in the mouse neocortex are independent from astrocytic calcium waves. Cereb Cortex 16: 237-246.

Hajnóczky G, Thomas AP. 1994. The inositol trisphosphate calcium channel is inactivated by inositol trisphosphate. Nature 370: 474-477.

Hajnóczky G, Robb-Gaspers LD, Seitz MB, Thomas AP. 1995. Decoding of cytosolic calcium oscillations in the mitochondria. Cell 82: 415-424.

Halestrap AP. 2009. Mitochondrial calcium in health and disease. Biochim Biophys Acta 1787: 1289-1290.

Hattori M, Suzuki AZ, Higo T, Miyauchi H, Michikawa T, Nakamura T, Inoue T, Mikoshiba K. 2004. Distinct roles of inositol 1,4,5-trisphosphate receptor types 1 and 3 in $\mathrm{Ca}^{2+}$ signaling. J Biol Chem 279: 11967-11975.

Hellman B, Gylfe E, Grapengiesser E, Lund P-E, Berts A. 1992. Cytoplasmic $\mathrm{Ca}^{2+}$ oscillations in pancreatic bcells. Biochim Biophys Acta 1113: 295-305.

Hofer T, Venance L, Giaume C. 2002. Control and plasticity of intercellular calcium waves in astrocytes: A modeling approach. J Neurosci 22: 4850-4859. 


\section{G. Dupont et al.}

Hoth M, Penner R. 1992. Depletion of intracellular calcium stores activates a calcium current in mast cells. Nature 355: 353-355.

Huang GN, Zeng W, Kim JY, Yuan JP, Han L, Muallem S, Worley PF. 2006. STIM1 carboxyl-terminus activates native SOC, Icrac and TRPC1 channels. Nat Cell Biol 8: $1003-1010$.

Keizer J, Levine L. 1996. Ryanodine receptor adaptation and $\mathrm{Ca}^{2+}(-)$ induced $\mathrm{Ca}^{2+}$ release-dependent $\mathrm{Ca}^{2+}$ oscillations. Biophys J 71: 3477-3487.

Keizer J. 1993. Calcium oscillations and waves: Is the $\mathrm{IP}_{3} \mathrm{R}$ $\mathrm{Ca}^{2+}$ channel the culprit? Biophys J 65: 1359-1361.

Kouchi Z, Fukami K, Shikano T, Oda S, Nakamura Y, Takenawa T, Miyazaki S. 2004. Recombinant phospholipase Czeta has high $\mathrm{Ca}^{2+}$ sensitivity and induces $\mathrm{Ca}^{2+}$ oscillations in mouse eggs. J Biol Chem 279: 10408-10412.

Kummer U, Olsen LF, Dixon CJ, Green AK, Bornberg-Bauer E, Baier G. 2000. Switching from simple to complex oscillations in calcium signaling. Biophys J 79: 1188-1195.

Kummer U, Krajnc B, Pahle J, Green AK, Dixon CJ, Marhl M. 2005. Transition from stochastic to deterministic behavior in calcium oscillations. Biophys J 89: 16031611.

Kwan CY, Takemura H, Obie JF, Thastrup O, Putney JW. 1990. Effects of methacholine, thapsigargin and $\mathrm{La}^{3+}$ on plasmalemmal and intracellular $\mathrm{Ca}^{2+}$ transport in lacrimal acinar cells. Am J Physiol 258: C1006-C1015.

LeBeau AP, Yule DI, Groblewski GE, Sneyd J. 1999. Agonistdependent phosphorylation of the inositol 1,4,5-trisphosphate receptor. A possible mechanism for agonistspecific calcium oscillations in pancreatic acinar cells. $J$ Gen Physiol 113: 851-871.

Lewis RS. 2003. Calcium oscillations in T-cells: Mechanisms and consequences for gene expression. Biochem Soc Trans 31: 925-929.

Li YX, Rinzel J. 1994. Equations for InsP $\mathrm{P}_{3}$ receptor-mediated $\left[\mathrm{Ca}^{2+}\right] \mathrm{i}$ oscillations derived from a detailed kinetic model: a Hodgkin-Huxley like formalism. J Theor Biol 166: $461-473$.

Li Y-X, Keizer J, Stojilkovic SS, Rinzel J. 1995. Ca ${ }^{2+}$ excitability of the ER membrane: an explanation for $\mathrm{IP}_{3}$-induced $\mathrm{Ca}^{2+}$ oscillations. Am J Physiol 269: C1079-C1092.

Liou J, Fivaz M, Inoue T, Meyer T. 2007. Live-cell imaging reveals sequential oligomerization and local plasma membrane targeting of stromal interaction molecule 1 after $\mathrm{Ca}^{2+}$ store depletion. Proc Natl Acad Sci 104: 9301-9306.

Marchant J, Callamaras N, Parker I. 1999. Initiation of $\mathrm{IP}_{3}$ mediated $\mathrm{Ca}^{2+}$ waves in Xenopus oocytes. EMBO J 18: 5285-5299.

Marhl M, Schuster S, Brumen M. 1998. Mitochondria as an important factor in the maintenance of constant amplitudes of cytosolic calcium oscillations. Biophys Chem 71: $125-132$.

Mercer JC, DeHaven WI, Smyth JT, Wedel B, Boyles RR, Bird GS, Putney JW. 2006. Large store-operated calciumselected currents due to co-expression of orail or orai2 with the intracellular calcium sensor, stim1. J Biol Chem 281: 24979-24990.
Meyer T, Stryer L. 1988. Molecular model for receptorstimulated calcium spiking. Proc Nat Acad Sci 85: 50515055.

Meyer T, Stryer L. 1991. Calcium spiking. Annu Rev Biophys Biophys Chem 20: 153-174.

Meyer T, Hanson PI, Stryer L, Schulman H. 1992. Calmodulin trapping by calcium-calmodulin-dependent protein kinase. Science 256: 1199-1202.

Mignen O, Thompson JL, Shuttleworth TJ. 2008. Both Orail and Orai3 are essential components of the arachidonate-regulated $\mathrm{Ca}^{2+}$-selective (ARC) channels. J Physiol (Lond) 586: 185-195.

Miyakawa T, Maeda A, Yamazawa T, Hirose K, Kurosaki T, Iino M. 1999. Encoding of $\mathrm{Ca}^{2+}$ signals by differential expression of $\mathrm{IP}_{3}$ receptor subtypes. EMBO J 18: $1303-$ 1308.

Nicou A, Serriere V, Hilly M, Prigent S, Combettes L, Guillon G, Tordjmann T. 2007. Remodeling of calcium signaling during liver regeneration in the rat. J Hepatol 46: 247-256.

Oh-Hora M. 2009. Calcium signaling in the development and function of T-lineage cells. Immunol Rev 231: 210-224.

Orci L, Ravazzola M, Coadic MLe, Shen Ww, Demaurex N, Cosson P. 2009. STIM1-induced precortical and cortical subdomains of the endoplasmic reticulum. Proc Natl Acad Sci 106: $19358-19362$.

Parekh AB, Putney JW. 2005. Store-operated calcium channels. Physiol Rev 85: 757-810.

Parekh AB, Fleig A, Penner R. 1997. The store-operated calcium current $\mathrm{I}_{\mathrm{CRAC}}$ : Nonlinear activation by $\mathrm{InsP}_{3}$ and dissociation from calcium release. Cell 89: 973-980.

Park CY, Hoover PJ, Mullins FM, Bachhawat P, Covington ED, Raunser S, Walz T, Garcia KC, Dolmetsch RE, Lewis RS. 2009. STIM1 clusters and activates CRAC channels via direct binding of a cytosolic domain to Orail. Cell 136: $876-890$.

Parvez S, Beck A, Peinelt C, Soboloff J, Lis A, MonteilhZoller M, Gill DL, Fleig A, Penner R. 2008. STIM2 protein mediates distinct store-dependent and store-independent modes of CRAC channel activation. FASEB J 22: $752-761$.

Petersen OH, Wakui M. 1990. Oscillating intracellular $\mathrm{Ca}^{2+}$ signals evoked by activation of receptors linked to inositol lipid hydrolysis: Mechanism of generation. J Membrane Biol 118: 93-105.

Politi A, Gaspers LD, Thomas AP, Hofer T. 2006. Models of $\mathrm{IP}_{3}$ and $\mathrm{Ca}^{2+}$ oscillations: Frequency encoding and identification of underlying feedbacks. Biophys $J$ 90: 3120-3133.

Prince WT, Berridge MJ. 1973. The role of calcium in the action of 5-hydroxytryptamine and cyclic AMP on salivary glands. J Exp Biol 58: 367-384.

Putney JW. 1986. A model for receptor-regulated calcium entry. Cell Calcium 7: 1-12.

Putney JW, Bird GS. 2008. Cytoplasmic calcium oscillations and store-operated calcium influx. J Physiol 586: 30553059.

Putney JW, Poggioli J, Weiss SJ. 1981. Receptor regulation of calcium release and calcium permeability in parotid gland cells. Phil Trans R Soc Lond B 296: 37-45. 
Renard D, Poggioli J, Berthon B, Claret M. 1987. How far does phospholipase $\mathrm{C}$ activity depend on the cell calcium concentration? A study in intact cells. Biochem J 243: 391-398.

Ribeiro CMP, Putney JW. 1996. Differential effects of protein kinase $\mathrm{C}$ activation on calcium storage and capacitative calcium entry in NIH 3T3 cells. J Biol Chem 271: 21522-21528.

Rink TJ, Jacob R. 1989. Calcium oscillations in non-excitable cells. Trends Neurosci 12: 43-46.

Rizzuto R, Pozzan T. 2006. Microdomains of intracellular $\mathrm{Ca}^{2+}$ : Molecular determinants and functional consequences. Physiol Rev 86: 369-408.

Rizzuto R, Pinton P, Carrington W, Fay FS, Fogarty KE, Lifshitz LM, Tuft RA, Pozzan T. 1998. Close contacts with the endoplasmic reticulum as determinants of mitochondrial $\mathrm{Ca}^{2+}$ responses. Science 280: 1763-1766.

Rizzuto R, Simpson AWM, Brini M, Pozzan T. 1992. Rapid changes of mitochondrial $\mathrm{Ca}^{2+}$ revealed by specifically targeted recombinant aequorin. Nature 358: 325-327.

Rosado JA, Sage SO. 2000. A role for the actin cytoskeleton in the initiation and maintenance of store-mediated calcium entry in human platelets. Trends Cardiovasc Med 10: $327-332$.

Saunders CM, Larman MG, Parrington J, Cox LJ, Royse J, Blayney LM, Swann K, Lai FA. 2002. PLC zeta: A spermspecific trigger of $\mathrm{Ca}^{(2+)}$ oscillations in eggs and embryo development. Development 129: 3533-3544.

Selivanov VA, Ichas F, Holmuhamedov EL, Jouaville LS, Evtodienko YV, Mazat JP. 1998. A model of mitochondrial $\mathrm{Ca}^{(2+)}$-induced $\mathrm{Ca}^{2+}$ release simulating the $\mathrm{Ca}^{2+}$ oscillations and spikes generated by mitochondria. Biophys Chem 72: 111-121.

Shuai JW, Yang DP, Pearson JE, Rudiger S. 2009. An investigation of models of the $\mathrm{IP}_{3} \mathrm{R}$ channel in Xenopus oocyte. Chaos 19: 037105.

Shuttleworth TJ. 1999. What drives calcium entry during $\left[\mathrm{Ca}^{2+}\right]_{\mathrm{i}}$ oscillations? - challenging the capacitative model. Cell Calcium 25: 237-246.

Shuttleworth TJ, Thompson JL, Mignen O. 2004. ARC channels: A novel pathway for receptor-activated calcium entry. Physiology (Bethesda) 19: 355-361.

Shuttleworth TJ, Thompson JL, Mignen O. 2007. STIM1 and the noncapacitative ARC channels. Cell Calcium 42: $183-191$.

Skupin A, Kettenmann H, Winkler U, Wartenberg M, Sauer H, Tovey SC, Taylor CW, Falcke M. 2008. How does intracellular $\mathrm{Ca}^{2+}$ oscillate: By chance or by the clock? Biophys J 94: 2404-2411.

Smith IF, Parker I. 2009. Imaging the quantal substructure of single $\mathrm{IP}_{3} \mathrm{R}$ channel activity during $\mathrm{Ca}^{2+}$ puffs in intact mammalian cells. Proc Natl Acad Sci 106: 6404-6409.

Smith IF, Wiltgen SM, Shuai J, Parker I. 2009. $\mathrm{Ca}^{(2+)}$ puffs originate from preestablished stable clusters of inositol trisphosphate receptors. Sci Signal 2: ra77.

Sneyd J, Falcke M. 2005. Models of the inositol trisphosphate receptor. Prog Biophys Mol Biol 89: 207-245.

Sneyd J, Charles AC, Sanderson MJ. 1994. A model for the propagation of intercellular calcium waves. Am J Physiol 266: C293-C302.
Sneyd J, Tsaneva-Atanasova K, Reznikov V, Bai Y, Sanderson MJ, Yule DI. 2006. A method for determining the dependence of calcium oscillations on inositol trisphosphate oscillations. Proc Natl Acad Sci 103: 1675-1680.

Sneyd J, Tsaneva-Atanasova K, Yule DI, Thompson JL, Shuttleworth TJ. 2004. Control of calcium oscillations by membrane fluxes. Proc Natl Acad Sci 101: 1392-1396.

Sneyd J, Wetton BT, Charles AC, Sanderson MJ. 1995. Intercellular calcium waves mediated by diffusion of inositol trisphosphate: A two-dimensional model. Am J Physiol 268: C1537-C1545.

Soboloff J, Spassova MA, Hewavitharana T, He LP, Xu W, Johnstone LS, Dziadek MA, Gill DL. 2006a. STIM2 is an inhibitor of STIM1-mediated store-operated $\mathrm{Ca}^{2+}$ entry. Curr Biol 16: 1465-1470.

Soboloff J, Spassova MA, Tang XD, Hewavitharana T, Xu W, Gill DL. 2006b. Orail and STIM reconstitute store-operated calcium channel function. J Biol Chem 281: 2066120665.

Streb H, Irvine RF, Berridge MJ, Schulz I. 1983. Release of $\mathrm{Ca}^{2+}$ from a nonmitochondrial store in pancreatic cells by inositol-1,4,5-trisphosphate. Nature 306: 67-68.

Swann K, Yu Y. 2008. The dynamics of calcium oscillations that activate mammalian eggs. Int J Dev Biol 52: 585-594.

Swillens S, Champeil P, Combettes L, Dupont G. 1998. Stochastic simulation of a single inositol 1,4,5-trisphosphate-sensitive $\mathrm{Ca}^{2+}$ channel reveals repetitive openings during 'blip-like' $\mathrm{Ca}^{2+}$ transients. Cell Calcium 23: 291-302.

Swillens S, Dupont G, Combettes L, Champeil P. 1999. From calcium blips to calcium puffs: theoretical analysis of the requirements for interchannel communication. Proc Natl Acad Sci 96: 13750-13755.

Tang Y, Othmer HG. 1994. A model of calcium dynamics in cardiac myocytes based on the kinetics of ryanodinesensitive calcium channels. Biophys J 67: 2223-2235.

Tang Y, Stephenson JL, Othmer HG. 1996. Simplification and analysis of models of calcium dynamics based on IP3-sensitive calcium channel kinetics. Biophys J 70: 246-263.

Tanimura A, Morita T, Nezu A, Shitara A, Hashimoto N, Tojyo Y. 2009. Use of fluorescence resonance energy transfer-based biosensors for the quantitative analysis of inositol 1,4,5-trisphosphate dynamics in calcium oscillations. J Biol Chem 284: 8910-8917.

Taylor CW, Thorn P. 2001. Calcium signalling: $\mathrm{IP}_{3}$ rises again ... and again. Current Biol 11: R352-R355.

Tepikin AV, Petersen OH. 1992. Mechanisms of cellular calcium oscillations in secretory cells. Biochim Biophys Acta 1137: 197-207.

Thomas AP, Renard DC, Rooney TA. 1992. Spatial organization of $\mathrm{Ca}^{2+}$ signaling and $\operatorname{Ins}(1,4,5) \mathrm{P}_{3}$ action. $A d v S e c$ ond Messenger Phosphoprotein Res 26: 225-263.

Thomas AP, Bird GStJ, Hajnóczky G, Robb-Gaspers LD, Putney JW. 1996. Spatial and temporal aspects of cellular calcium signalling. FASEB J 10: 1505-1517.

Thomas D, Lipp P, Tovey SC, Berridge MJ, Li W, Tsien RY, Bootman MD. 2000. Microscopic properties of elementary $\mathrm{Ca}^{2+}$ release sites in non-excitable cells. Current Biol 10: 8-15. 


\section{G. Dupont et al.}

Thul R, Smith GD, Coombes S. 2008. A bidomain threshold model of propagating calcium waves. J Math Biol 56: 435-463.

Tsien RW, Bean BP, Hess P, Lansman JB, Nilius B, Nowycky MC. 1986. Mechanisms of calcium channel modulation by $\beta$-adrenergic agents and dihydropyridine calcium agonists. J Mol Cell Cardiol 18: 691-710.

Van Breemen C, Farinas B, Gerba P, McNaughton ED. 1972. Excitation-contraction coupling in rabbit aorta studied by the lanthanum method for measuring cellular calcium influx. Circ Res 30: 44-54.

Vazquez G, Wedel BJ, Aziz O, Trebak M, Putney JW. 2004. The mammalian TRPC cation channels. Biochim Biophys Acta 1742: 21-36.

Ventura AC, Sneyd J. 2006. Calcium oscillations and waves generated by multiple release mechanisms in pancreatic acinar cells. Bull Math Biol 68: 2205-2231.

Wang I, Politi AZ, Tania N, Bai Y, Sanderson MJ, Sneyd J. 2008. A mathematical model of airway and pulmonary arteriole smooth muscle. Biophys J 94: 2053-2064.

Wedel B, Boyles RR, Putney JW, Bird GS. 2007. Role of the store-operated calcium entry proteins, Stiml and Orail, in muscarinic-cholinergic receptor stimulated calcium oscillations in human embryonic kidney cells. J Physio 579: 679-689.

Williams GS, Molinelli EJ, Smith GD. 2008. Modeling local and global intracellular calcium responses mediated by diffusely distributed inositol 1,4,5-trisphosphate receptors. J Theor Biol 253: 170-188.

Woods NM, Cuthbertson KS, Cobbold PH. 1986. Repetitive transient rises in cytoplasmic free calcium in hormonestimulated hepatocytes. Nature 319: 600-602.

Zahradnikova A, Zahradnik I. 1996. A minimal gating model for the cardiac calcium release channel. Biophys J 71: 2996-3012.

Zen S, Li B, Zeng S, Chen S. 2009. Simulation of spontaneous $\mathrm{Ca}^{2+}$ oscillations in astrocytes mediated by voltage-gated calcium channels. Biophys J 97: 24292437.

Zheng L, Stathopulos PB, Li GY, Ikura M. 2008. Biophysical characterization of the EF-hand and SAM domain containing $\mathrm{Ca}^{2+}$ sensory region of STIM1 and STIM2. Biochem Biophys Res Commun 369: 240-246. 


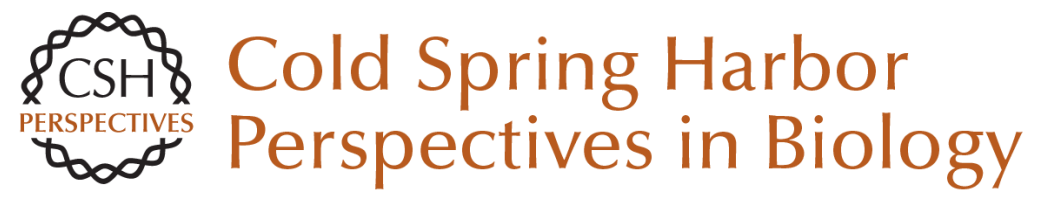

\section{Calcium Oscillations}

Geneviève Dupont, Laurent Combettes, Gary S. Bird and James W. Putney

Cold Spring Harb Perspect Biol 2011; doi: 10.1101/cshperspect.a004226 originally published online December 8, 2010

\section{Subject Collection Calcium Signaling}

The Endoplasmic Reticulum-Plasma Membrane Junction: A Hub for Agonist Regulation of $\mathrm{Ca}^{2+}$ Entry

Hwei Ling Ong and Indu Suresh Ambudkar

Calcium-Handling Defects and Neurodegenerative Disease

Sean Schrank, Nikki Barrington and Grace E. Stutzmann

Lysosomal $\mathrm{Ca}^{2+}$ Homeostasis and Signaling in Health and Disease

Emyr Lloyd-Evans and Helen Waller-Evans

\section{$\mathrm{Ca}^{2+}$ Signaling in Exocrine Cells}

Malini Ahuja, Woo Young Chung, Wei-Yin Lin, et al.

Functional Consequences of Calcium-Dependent Synapse-to-Nucleus Communication: Focus on Transcription-Dependent Metabolic Plasticity Anna M. Hagenston, Hilmar Bading and Carlos Bas-Orth

Identifying New Substrates and Functions for an Old Enzyme: Calcineurin Jagoree Roy and Martha S. Cyert

Fundamentals of Cellular Calcium Signaling: A Primer

Martin D. Bootman and Geert Bultynck
Primary Active $\mathrm{Ca}^{2+}$ Transport Systems in Health and Disease Jialin Chen, Aljona Sitsel, Veronick Benoy, et al.

Signaling through $\mathrm{Ca}^{2+}$ Microdomains from Store-Operated CRAC Channels Pradeep Barak and Anant B. Parekh

Structural Insights into the Regulation of $\mathrm{Ca}^{2+}$ /Calmodulin-Dependent Protein Kinase II (CaMKII) Moitrayee Bhattacharyya, Deepti Karandur and John Kuriyan

Store-Operated Calcium Channels: From Function to Structure and Back Again Richard S. Lewis

Bcl-2-Protein Family as Modulators of $\mathrm{IP}_{3}$

Receptors and Other Organellar $\mathrm{Ca} 2+$ Channels Hristina Ivanova, Tim Vervliet, Giovanni Monaco, et al.

Calcium Signaling in Cardiomyocyte Function Guillaume Gilbert, Kateryna Demydenko, Eef Dries, et al.

Cytosolic $\mathrm{Ca}^{2+}$ Buffers Are Inherently $\mathrm{Ca}^{2+}$ Signal Modulators Beat Schwaller

For additional articles in this collection, see http://cshperspectives.cshlp.org/cgi/collection/

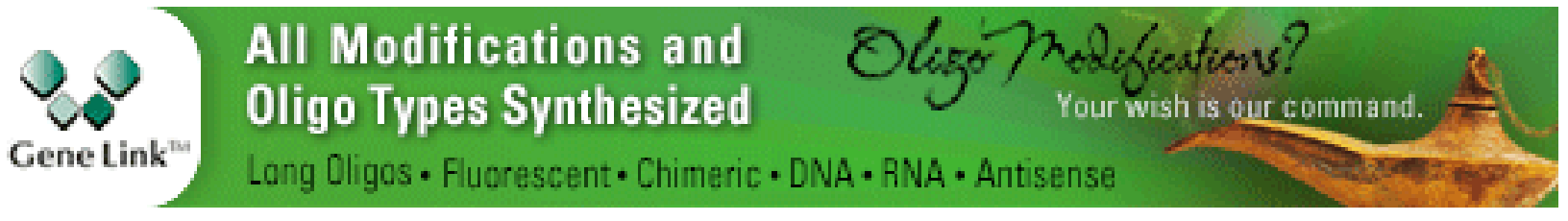


Role of Two-Pore Channels in Embryonic Development and Cellular Differentiation Sarah E. Webb, Jeffrey J. Kelu and Andrew L. Miller

\section{Organellar Calcium Handling in the Cellular \\ Reticular Network}

Wen-An Wang, Luis B. Agellon and Marek Michalak

For additional articles in this collection, see http://cshperspectives.cshlp.org/cgi/collection/

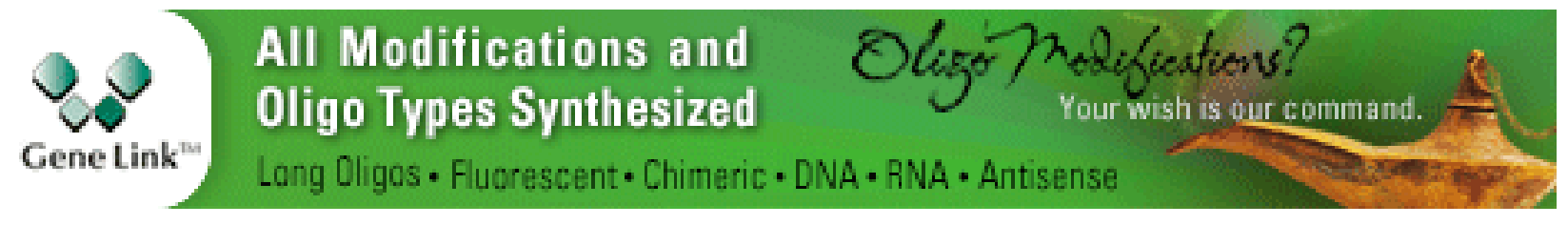

Copyright @ 2011 Cold Spring Harbor Laboratory Press; all rights reserved 